\title{
Two Anonymous Sermons from Manuscript Ms 434 in Leipzig University Library*
}

\author{
Anna Pumprová \\ (University of Ostrava)
}

\begin{abstract}
This article presents an edition of two sermons with the incipits Ingredere, benedicte Domini and Posuit Deus hominem which have been preserved at the end of manuscript Ms 434 in Leipzig University Library. Although previous research considered both texts as belonging to Peter of Zittau's collection Sermones de principalibus festis, preserved as part of the same manuscript, an analysis of the manuscript and the texts of both sermons supports the conclusion that these sermons were in fact written by an unknown member of the Zbraslav monastery in the second half of the 14th century.
\end{abstract}

\section{Keywords}

sermon; Cistercian writing; Zbraslav monastery; Peter of Zittau

Although the Cistercian monastery in Zbraslav was an important centre of literary production in medieval Bohemia, still very little is known about the writings of the monastery's members (with the exception of the Chronica Aulae regiae and the Malogranatum), and almost none of the surviving texts written by the Zbraslav monks have been published in edited form. ${ }^{1}$ Among these texts are sermons that have been preserved as part of manuscript Ms 434 in Leipzig University Library. ${ }^{2}$ The manuscript is a parchment codex written during the 14th century at the Zbraslav monastery; the codex probably found its way into the Leipzig library along with manuscripts from the Cistercian

* This article was written as part of the Czech Science Foundation (GAČR) project no. 16-09491S - Edice kázáni Petra Žitavského (Edition of the Sermons of Peter of Zittau).

1 A brief overview of the literary activities of the monks at the Zbraslav monastery is given in Charvátová (2002: pp. 246-250). The Chronica Aulae regiae has been published in several editions (most recently Emler 1884); a new publication of the text - edited by Anna Pumprová, Libor Jan, Robert Antonín, Demeter Malaták, Libor Švanda and Zdeněk Žalud - is currently in press. Other Zbraslav texts that have been published include a small-scale poetic text entitled De omni statu mundi, dating from the mid-14th century, cf. Vidmanová (1998), and the edificatory poem Formula ad edificacionem fratris et monachi devoti, erroneously attributed to Peter of Zittau, cf. Nechutová (1999).

2 A description of the manuscript is given in Helssig (1995: pp. 678-679). 
monastery in Altzelle - which served as a place of refuge for some of the Zbraslav monks during the turbulent events that led up to the outbreak of the Hussite Wars. ${ }^{3}$

A note written by hand in the 15th century on the end-sheet of the codex summarizes the contents of the codex as follows: Item registrum: item Sermones abbatis Aulae regiae de principalibus festis, item Exhortatio ad bonum. The first of the listed items - a collection of sermons to be given on the most important feast days of the Cistercian order - occupies a large majority of manuscript Ms 434 (fol. $1 \mathrm{r}-169 \mathrm{v}^{\mathrm{a}}$ ), and at several points in the text the author is given as Peter of Zittau, the third Abbot of the Zbraslav monastery (13161339) and the author of Chronica Aulae regiae (Zbraslav chronicle). The basic text of the Sermones de principalibus festis is written in a single hand and dates from the first half of the 14th century; minor corrections, adjustments and notes were written in a different hand during the same period - most probably by the author himself. ${ }^{4}$ The collection is preceded by a prologue and consists of two books, in which the sermons are arranged in chronological order of the main Cistercian feast days in the liturgical year. The sermons were mainly based on speeches given by the Abbot on liturgical occasions stipulated by the order to an audience of monks gathered in the chapter, ${ }^{5}$ though a small number of them were probably written for the secular clergy. ${ }^{6}$ The work was intended to serve as an aid for preachers seeking material and models for presenting the material in sermons on the above-mentioned (and other) occasions. ${ }^{7}$ The prologue of the collection, and each sermon in it, begin with a large coloured initial letter, and the lower edges of the folios bear the distinctions ${ }^{8}$ of the individual sermons in order to help future users find their way around the text. Each book was intended to include a list of these distinctions. In the first book of sermons, some work was done on compiling the list (fol. 98v-100v), but it was not completed; the list contains only key words, some of them accompanied by the number of the page on which the relevant text appears. In the second book, a blank

3 For information on Altzelle as a refuge for the Zbraslav monks cf. Lauterer (1964: p. 97).

4 This part of Ms 434 contains a specific method for identifying text to be omitted when copying (the word va-cat, whose first syllable marks the beginning of the passage to be omitted and whose second syllable marks the end of the passage); the same specific method is found in the autograph of the second book of the Chronica Aulae regiae; cf. e.g. UB Leipzig, Ms 434, fol. 6v $\mathrm{v}^{\mathrm{a}}, 13 \mathrm{r}^{\mathrm{a}}$, 16v $\mathrm{v}^{\mathrm{a}}$; Bibliotheca apostolica Vaticana, Roma, Cod. Pal. Lat. 950, fol. 9r-v, 19r, 26v. For information on Peter's autograph of the second book of the Chronica Aulae regiae cf. Bláhová (2006), Hledíková (2013), Pumprová (2012).

5 For more information see Pumprová (2006a).

6 The sixth sermon on the feast of the Nativity of Jesus in the second book of the collection, which is stylistically more complex than the other texts, is explicitly identified in the rubric as being aimed ad clerum (cf. Ms 434, fol. $115 \mathrm{r}^{\mathrm{b}}-116 \mathrm{v}^{\mathrm{a}}$ ). The first sermon on the feast of the Apostles Peter and Paul discusses the qualities that are required of prelates (fol. $162 \mathrm{v}^{\mathrm{a}}-164 \mathrm{v}^{\mathrm{a}}$ ). One of the occasional sermons at the end of the first book of the collection is entitled De sacerdote (fol. $93 \mathrm{v}^{\mathrm{b}}-95 \mathrm{v}^{\mathrm{a}}$ ); it emphasizes the dignity of the clergy, and was evidently intended to be used at ordinations of priests (cf. fol. 95 $\mathrm{r}^{\mathrm{a}}-\mathrm{r}^{\mathrm{b}}$ : In celis quidem, quando iste miles | novus sacerdos hodie missam celebrat, tota celestis curia exultat, angeli gaudent, sancti exultant, quando celorum Dominus se in sacramentum mirabiliter transfigurat.).

7 Cf. Pumprová (2006b).

8 In medieval sermons, distinctions were generally based on explanations of various aspects of a single word, drawing on citations from scripture and other authorities. Cf. d'Avray (1999: p. 662). 
space was left for the list of distinctions (fol. 170r-172v); the second book also lacks a list of sermons, which was to be inserted on the blank folios 101r-102r.

Two more texts follow after the blank folios 170r-172 in manuscript Ms 434 . The first sermon (on fol. 173r-176r) is marked with the rubricated heading Exhortacio ad bonum, which is mentioned on the end-sheet of the codex, and it begins with the words: Ingredere, benedicte Domini, cur foris stas? Preparavi domum, Genesis XXIIII. Verba proposita, que Laban plus per infusionem Sancti Spiritus quam revelacione carnis proprie et sangwinis informatus sub typo Cristi ad nuncium Abrahe pro sui filii Ysaac coniugio delegatum sacra docet Pagina protulisse... Explicit: ...ubi nullum fastidium, sed permanens gaudium. Ad quod nos perducat Ihesus Marie Filius, cui cum Patre et Spiritu sancto honor et gloria per omnia secula seculorum, amen. The second sermon (fol. 176v-178v) addresses a theme taken from the beginning of the Book of Genesis (Gen 2:15), and it begins with the words: Posuit Deus hominem in paradyso voluptatis, ut operaretur et custodiret illum, Genesis I. Secundum spiritalem huius verbi intelligenciam describitur institucio, qualitas et operacio vel officium prelatorum. Explicit: Rogemus Dominum, ut vineam in paradyso ecclesie consociati custodiamus, ut ad eterna gaudia perveniamus. Quod nobis prestet, qui vivit et regnat per omnia secula seculorum, amen. Although the older literature identifies both texts as belonging to the collection of sermons by Peter of Zittau, ${ }^{9}$ more recent research leads us to a different conclusion. The aim of this article is to present an edition of the final part of manuscript Ms 434 and to give details of new findings brought by the analysis of the manuscript record of both sermons and their texts.

Manuscript. As has been mentioned above, the formal apparatus of the collection of sermons by Peter of Zittau was not comted; however, space was left to add the missing list of sermons and the list of distinctions, and both of the sermons that follow the collection Sermones de principalibus festis were written in a new separate quire (quaternion). With regard to the writing of the two last texts in codex Ms 434, it should be noted that these texts are written in much more broken lettering than is the case with the sermons from Peter's collection. The hand that wrote the basic texts must therefore date from after Peter of Zittau's death $(\uparrow 1339)$, some time in the second half of the 14th century. Some words from the original text were omitted by the scribe; others were left out because he could not read them, and others were incorrectly read and transcribed. ${ }^{10}$ Most of these errors were corrected by another hand dating from the same period, writing in a lighter-coloured ink and using a more casual, rounded style of lettering. ${ }^{11}$ The texts of

9 Cf. Schneyer (1972: pp. 807-817); Helssig (1995: p. 679). Both texts were listed as part of the collection of Peter's sermons by Johann Loserth, despite the fact that he had doubts about Peter's authorship; cf. Loserth (1881: p. 397, note 2).

10 E.g. on fol. $174 \mathrm{r}^{\mathrm{a}}$ the missing non has been added in the right margin next to the 12th line from the bottom; the same correction can also be found in the left margin next to the $21 \mathrm{st}$ line on fol. $174 \mathrm{v}^{\mathrm{a}}$; on fol. $176 \mathrm{v}^{\mathrm{b}}$ the missing est has been added in the left margin next to the 4th line; on the 7th line from the bottom of fol. $174 \mathrm{v}^{\mathrm{a}}$ the word rite (which makes no sense) has been corrected to in te; on the 6th line from the bottom of fol. $176 \mathrm{v}^{\mathrm{a}}$ the incorrect qui has been corrected to quibus; on the 6th line from the bottom of fol. $178 \mathrm{r}^{\mathrm{b}}$ a blank space has been filled with the words ad cadavera venerunt, etc. However, not all errors have been corrected.

11 In some cases, for the sake of clarity, this hand expanded the scribe's abbreviations on the margin of the 
both sermons are complete, but its formal apparatus was (as in the collection of sermons by Peter of Zittau) not completed. Rubrication was used only on the first page of this part of the codex (on folio 173r) for the heading, the large initial letter at the beginning of the first sermon and the beginnings of sentences and paragraphs in the text; on the following pages spaces were left blank for this purpose.

\section{Ingredere, benedicte Domini}

The sermon with the rubricated heading Exhortatio ad bonum displays the typical structure of a thematic sermon. ${ }^{12}$ The citation of the central verse from the Bible - the theme - is followed by an introduction to the sermon (prothema), which begins by outlining a basic interpretative framework for the chosen passage from scripture: the words with which Laban welcomed Abraham's messenger, who had come seeking a wife for Isaac, are explained in the spiritual sense and typologically interpreted with reference to the situation for which the sermon was intended. According to the sermon, Laban said these words as a prefiguration of Christ (sub typo Cristi), and Christ - today and at all times - calls upon every monk to follow him (cf. § 1-2). Viewed from this perspective, the greeting benedicte is addressed to the monks, so the preacher also addresses the following distinction of the word "blessed" to the monks: a blessed man can be recognized by the fact that 1) he has been chosen by God to renounce the world and external affairs in order to live a life of contemplation, following the guidance given by Bernard of Clairvaux and also by Cicero, according to whose example monks should experience the absence of other people and the release from manual labour as the direct opposite of solitude and leisure (§ 3-4); 2) a blessed man is rebuked and instructed by God (§5); 3) a blessed man has been elevated by God in order to bring nations to rectitude and, thanks to his virtues, to contemplate God's glory through his inner vision $(\S 6)$. Before the transition to the main part of the sermon, it was conventional for the speaker to acknowledge his inadequacy as a preacher, and to conclude this captatio benevolentiae by asking the Virgin Mary for assistance and reciting the Ave Maria (§ 7).

The sermon itself begins by dividing the theme (divisio thematis) into three main parts, termed the principale membrum $(\S 8) .{ }^{13}$ The preacher thus states that the theme consists of: 1) God's attraction and invitation (attraccio seu invitatio Domini) in the words Ingredere, benedicte Domini; 2) a rebuke to the invitee who is hesitant to arrive (tardantis invitati redargucio seu increpacio): Cur foris stas?; 3) the preparation of an eternal abode (possessionis eterne preparacio): Preparavi domum. Before developing and expanding on each of these three parts (a process which theoretical manuals for preachers termed dilatatio, prosecutio

folio, writing out the word in full. E.g. in the bottom margin of fol. $173 \mathrm{v}^{\mathrm{b}}$ he wrote diviciis (expanding the abbreviation in the third line from the bottom), and on fol. $176 \mathrm{r}^{\mathrm{a}}$ the word facturi is written out in the right margin next to the 10 th line.

12 On the structure of thematic sermons cf. e.g. Briscoe (1992: passim, especially pp. 54-58); Bériou (2000: pp. 370-382); d'Avray (1996: pp. 662-665).

13 The same term for these parts of the sermon is also used in the sermons by Peter of Zittau. 
thematis or, like the preceding part, divisio), ${ }^{14}$ the preacher interprets them as a reference to the persons of the Holy Trinity - the power of the Father, the wisdom of the Son, and the goodness of the Holy Spirit (§ 9-11).

The explanation of the first part of the theme (primum principale membrum, $\$ 12-19$ ), concerning God's invitation and attraction of the invitee, draws on three manifestations of attraction that can be found in nature (§ 12): the preacher states that these are similarity (people of the same occupation love each other more, and similar birds fly in similar ways), places at low elevations (water flows downwards from slopes to these places), and warmth (the heat of the sun attracts water from the earth up into the clouds). All three forms of attraction are likened to the relationship between God and a monk - and the preacher reminds his audience of the demands that this relationship places on them. Just as Christ became similar to man, so a monk must become similar to Him - by means of patience $(\S 15)$, a blameless life $(\S 16)$, obedient behaviour $(\S 17)$, humility $(\S 18)$, and the reciprocation of God's love $(\S 19)$. The preacher specifically calls on the monks to bear rebukes from their superiors (and also from people of lower status) joyously and without complaint - to react mildly to such rebukes, or rather to remain silent, as Christ remained silent in the face of unjust accusations $(\S 15)$. In accordance with the monks' vow of obedience, they must obey their superiors without delay and with respect, otherwise they would be committing theft, perjury and lies $(\S 17)$. They must also be careful to ensure that their humble clothing does not conceal pride ( $\$ 18)$. The monks are called upon to reciprocate God's love through a paraphrase of the words of the groom and bride from the Song of Songs ( $\$ 19$ ). The preacher's explanations in the first part of the sermon are supported by a number of citations from various books of the Bible as well as several statements (either explicit or concealed) from the writings of Bernard of Clairvaux.

In the second part of the text of the sermon (secundum membrum principale, $\$ 21-24$ ) the preacher focuses his explanation on the notion of rebukes. He distinguishes two types of rebuke - rebukes given by man and rebukes given by God. He begins by listing five reasons for rebukes given by man: to obey God, to avoid sin, to cause people to fear sin, to bring them to love and goodness, and, through the rebuke, to achieve God's grace and a build good reputation among people $(\$ 21)$. He then lists five ways in which a person should issue a rebuke to another person: justly, constantly, mildly, harshly, and wisely ( $\$ 22)$. Finally, he gives three ways in which man is rebuked by God (\$23-24): angry rebukes (in ira) issued to those who are to gain righteousness in purgatory, furious rebukes (in furore) issued to those who are to be eternally damned, and equitable rebukes (in equitate) issued to those who are still living in their earthly body. In this part of the sermon, the preacher's words remain on the general level of moral catechesis, without taking special account of the monastic audience; the most frequently cited authority here is the Glossa ordinaria..$^{15}$

14 Cf. Briscoe (1992: pp. 56-57).

15 In this part of the sermon, the author of Ingredere refers to several patristic authorities. All quotations seem to be taken from an unidentified intermediary source (a florilegium or a preacher handbook). 
In the explanation of the third part of the theme (tercium membrum principale), the preparation of the abode, the preacher - in accordance with the usual procedure in medieval Biblical exegesis ${ }^{16}$ - elaborates various meanings of the word domus. He distinguishes between material abodes $(\S 24)$ prepared by man for man - both in the literal sense (houses made of stone and wood) and in the figurative sense (the grave). He then interprets domus in the moral sense, as an abode prepared by the soul for its groom, the arrival of God's mercy ( $\$ 25)$. It is evident that the preacher considers the intimate mystical communion between the soul of man and God to be a topic of particular interest for his audience, as he adopts a more personal tone in this part of the text (more frequently addressing the audience and using first person plural pronouns) and - as in the part of the text which explains how God attracts man through the glow of his love - he draws on the text of the Song of Songs and the thoughts of Bernard of Clairvaux. As a postscript he adds a brief explanation of the word domus in the anagogic sense (\$26), as an abode prepared by God in heaven for His faithful. The sermon also includes the final conclusio, in the form of the conventional doxological formula ad quod nos perducat...

Although the preacher addresses his listeners in a highly general way, giving no hint as to the precise identity of the audience (dilectissimi, dilectissimi fratres, dilectissimi cristiani, karissimi fratres), the close connection of some parts of the sermon Ingredere, benedicte Domini with issues of relevance to monastic life clearly indicates that the sermon was intended for use in monasteries. The author's noticeable fondness for citing the words of Bernard of Clairvaux, and his use of the phrase "our holy father Bernardus" (beatus pater noster Bernhardus, § 4), are in keeping with the place of origin of codex Ms 434, the Cistercian monastery in Zbraslav. It can also be no coincidence that the sermon Ingredere, benedicte Domini contains the following citations from authorities: in connection with the statement that if a person remains silent when witnessing his neighbour sinning, he himself is committing a sin, the preacher cites an elegiac distichon which was widespread in the Middle Ages (cf. Walther: 28993): Si quis delinquit, ut Paulus apostolus inquit, / qui consentit ei, fit reus ipse rei (\$ 20); this couplet was used by Peter of Zittau in the second metre of Chapter 91 in the first book of the Zbraslav Chronicle. Similarly, the statement quem semel vidisse omnia est scivisse $(\$ 16)^{17}$ occurs several times in an identical form in Peter's collection Sermones de principalibus festis. As a member of the Zbraslav monastery, the author of the sermon Ingredere, benedicte Domini may have been familiar with Peter's work, or he may have used the same sources (florilegia) when writing his texts. The sermon Ingredere, benedicte Domini differs markedly from Peter of Zittau's writings - in its length (it is almost one third longer than the longest sermon in the collection Sermones de principalibus festis), in its more complex style, and in its considerably more frequent citations from authorities. The sermon does not contain any indications of having been connected with a particular feast day in the ecclesiastical year, on which (according to the instructions issued by the General Chapter of the Cistercian order)

16 On the fourfold sense of the Bible as a method of Biblical exegesis and its use in sermons, cf. especially de Lubac (1959-1964); Dobschütz (1921); Caplan (1929); Smalley (1931).

17 This is a variation of the widespread sentence quem semel vidisse est omnia didicisse, which some medieval texts attribute to Augustine Aurelius. 
the Abbot or a designated monk would give a sermo to an audience of monks gathered in the chapter; ${ }^{18}$ however, it may have been read on a different occasion in the life of the community, e.g. during a visitation. ${ }^{19}$

\section{Posuit Deus hominem}

The second of the sermons analyzed in this paper does not contain any specification at the head of the page; however, it is clear from a brief note In eleccione prelati ("at the election of a prelate"), written by a different hand in the bottom margin of fol. 176r, that it was intended for a different audience than the first sermon. Like the preceding text, it too is a thematic sermon, though in comparison with Ingredere, benedicte Domini its structure is less formal: it lacks a prothema with a captatio benevolentiae and a prayer, and in the explanation of the individual parts of the theme the preacher does not use the designation principale membrum, unlike in the first sermon. In the written form in which it has been preserved, this second sermon begins with the division of the theme into three parts according to its religious meaning: the words of Genesis 2:15 are said by the preacher to describe who should appoint a prelate (God), what the prelate should be (a man), and what his tasks and activities should be (to work and guard the garden of delights) ( $\$ 1)$.

The elaboration of the individual parts of the theme - focusing on various aspects of a prelate's actions - is preceded by an interpretation of the phrase paradisus voluptatis (§ 2-8). The garden of paradise is identified with the Church in its earthly form of existence (ecclesia militans), which abounds with many spiritual delights. The characteristics of this spiritual paradise are derived from the characteristics of the garden of delights as described in Genesis (especially Gen 2:8-10) and from the explanation of its literal meaning in the Glossa ordinaria: it is a paradise which is irrigated with water, bears fruits and is located in a beautiful place. In the earthly Church, this corresponds with three groups of believers: the penitent (penitentes), the proficient (proficientes) and the perfect (perfecti). The preacher illustrates the typical characteristics of each of these groups using citations from the Bible. He briefly reflects on the notion of the three states in man's spiritual journey to God - an idea which was generally popular in the mystical tradition, and a subject which was given a detailed treatment in the edificatory text Malogranatum, written at the Zbraslav monastery around the middle of the 14 th century. ${ }^{20}$

The explanation of the first part of the theme (\$9-11) cites words from the Epistle to the Hebrews (5:4) - And no one takes this honour on himself, but he receives it when called by God, just as Aaron was - interpreting this passage as a criticism of dishonest practices

18 For details on Cistercian monastic preaching cf. Muessig (1998: p. 14); Kienzle (2000: p. 271).

19 Two sermons of this type - a sermon for a visitation and an edificatory sermon for an unspecified occasion - are appended to the liturgical sermons at the end of the first book in Peter of Zittau's collection Sermones de principalibus festis.

20 For information on the Malogranatum and the teaching on the three spiritual states cf. Gerwing (1986: pp. 159-170; 2004). 
that were common in connection with the appointment of both high- and low-ranking Church officials at the time. The preacher points out that many who seek ecclesiastical benefice behave entirely without shame, even resorting to violence in order to further their ambitions. This occurs even in the Roman Curia; aspirants to this high office gain the favour of executors who are responsible for the administration of prebends, and then, motivated by incredible levels of ambition and covetousness, desire the death of living persons so that they can become their successors ( $\$ 9$ ). If a bishop or abbot reaches an advanced age, the canons or monks in a monastery begin to compete among themselves, forming groups and alliances in an effort to gain this office. When a bishop dies, each group lobbies on behalf of its own candidate, and the responsible procurator in the Curia ultimately makes the appointment depending on which group pays more for, as the preacher sarcastically adds, only the one who stands firm to the end will be saved (Matt 10:22; § 10).

To illustrate the battle for the office of prelate, the preacher skilfully cites well-known situations from the Bible: the children who jostled each other within Rebekah's womb (Gen 25:22), the twins borne by Tamar, which struggled against each other to emerge from her womb first (Gen 38:18-29), and the dispute between the sons of the Tekoan woman (2 Sam 14:4-6). When describing similar conflicts accompanying the election of a new Abbot, the preacher ( $\$ 11)$ ironically refers to the scene in which the Apostle Peter was liberated from prison (Acts 12:7-8): if an iniquitous candidate is chosen and wishes to ensure that he will be appointed to the office, he sends an angel as his messenger, who strikes Peter on the side (i.e. the auxiliary bishops, episcopi collaterales) ${ }^{21}$ with a silver hammer and says: "Get up quickly before our enemies arrive, and persuade the Bishop to appoint our chosen man!" And they then outdo each other in their praise of the iniquitous candidate. The preacher adds that many prelates have been appointed to the altar in this illegal manner, and that the same applies to lower-ranking officials, who are appointed by friends and relatives immediately when the post becomes vacant $(\S 11)$.

The explanation of the second part of the theme - the word homo, in relation to the characteristics of a prelate $(\S 12-18)$ - is based on the definitions of man, animal and accident, concepts which were widely known among medieval scholars from the study of logic in Boethius's translation of Porphyry's Isagoge, the introduction to Aristotle's Categories: ${ }^{22}$ "a man is a rational and mortal animal" (animal rationale mortale), "an animal is a living, sentient substance" (animal est substantia animata sensibilis), and "an accident is that which may be either present or absent, without destroying the subject" (accidens est, quod adest et abest praeter subiecti corruptionem). First, the preacher explains (\$12) that a prelate, as a man (homo) and an animal (animal), should be a substance, and not merely an accident, which is sometimes present and sometimes absent. The metaphor is then used to criticize those who receive numerous prebends and who believe that their nature is that of an accident: at one church they serve in person as the priest, while at another church they merely come to collect money; they do not care for their flock, but are

21 From the second half of the 14th century the Prague Diocese regularly had 2-3 auxiliary bishops; cf. Hledíková (2002: p. 145). 
merely interested in the wool from the sheep. However, they differ from a true accident in that their behaviour destroys the subject - i.e. the Church. This is the only point in the sermon at which the preacher explicitly addresses the audience - who can be assumed to consist of secular priests in charge of parishes - and calls on them to ensure that their nature remains that of an accident (in that they will not destroy the subject) and also that of a substance (in that they will always be present at their churches) (§ 13). The problem of the absence of prelates and priests from their places of work was discussed at numerous synods of the Prague Diocese during the second half of the 14th century. ${ }^{23}$

The second characteristic of an animal - that it is living (animatus) - is discussed in relation to the courage with which a prelate should curb wayward members of his flock (§ 14). Here too the preacher finds fault with many prelates, who act in precisely the opposite manner: they are lenient towards the proud and wealthy, while they oppress the poor and wretched; they exercise their power over a leaf carried away by the wind; they see blemishes on a priest in the furthest reaches of their diocese, while they are unable to see a blemish in their own house. The preacher finds parallels of such prelates in the world of nature, likening them to birds of prey and vultures. A prelate must therefore be not only courageous, but also sentient (sensibilis); he must feel sympathy with penitents, and he must be aware of the spiritual and bodily ailments of his subordinates $(\$ 15)$. The last two characteristics of a man - as a rational (racionale) and mortal (mortale) animal - are explained briefly, without any negative examples taken from contemporary ecclesiastical life: a prelate should abound with knowledge and should think of his own death in order to prevent him from sinning (\$ 16-17).

The main explanation of the second part of the theme - built around references to Porphyry - is followed by an additional section $(\S 18)$ in which the preacher points out the difference between a man and a lion, and - drawing on several typical characteristics of this beast of prey - discusses other vices that can be found in prelates. Particularly, he states, they should eschew malodorous breath, i.e. harmful speech, verbosity, lies and slander. Instead, they should follow the example of monks talking at a table, with one monk reading and the other correcting him. Prelates should also not have the vicious claws and greedy teeth of a lion - which symbolize avarice and gluttony. The third part of the theme $(\S 19)$, related to the job and tasks of prelates, is elaborated only cursorily, via several citations from the Bible; it is evident that the preacher's main focus in the sermon was on issues connected with the first and second parts of the theme.

The style of this second sermon is similar to that of the first, and it too is relatively lengthy (only the two longest sermons in Peter of Zittau's collection are longer). The text of Posuit Deus hominem also differs from Peter's sermons in that it pays particular attention to criticizing contemporary practices in appointments to ecclesiastical offices and the inappropriate behaviour of many prelates - as well as in the vehement (and even sarcastic) tone with which these practices are described. The difference becomes particularly apparent if we compare the text of Posuit Deus hominem with the first of Peter's sermons on the Feast of St Peter and St Paul in the second book of the collection

23 At the synods in 1343, 1349, 1386-1387, 1393-1394, 1405 and 1406; cf. Polc (1994: p. 39). 
Sermones de principalibus festis (fol. $162 \mathrm{v}^{\mathrm{a}}-164 \mathrm{v}^{\mathrm{a}}$ ). This sermon deals with largely the same question as Posuit Deus hominem - i.e. what qualities are required of those seeking to gain the office of a prelate - and some of the means used in the text are likewise the same. Peter of Zittau focuses his attention on describing the necessary qualities of a candidate in a positive manner, drawing examples from St Peter and St Paul: prelates should be chosen by Christ (i.e. via a canonical election); they should lead an exemplary life; they should abound with wisdom and knowledge; they should instruct and teach their flock; they should be resolutely good and aware of their own weakness, in order to be merciful. The fact that candidates do not always possess these qualities is conveyed by Peter in a relatively implicit manner, in connection with the requirement for canonical elections; he states that Peter and Paul were chosen by Christ himself, not through the instrument of men, as prelates do in return for money (i.e. simony), and that the Apostles did not actively seek office, as ambitious men do. ${ }^{24}$ In this connection Peter cites the same words from the Epistle to the Hebrews (5:4) that are used by the author of Posuit Deus hominem in his discussion of the appointment of prelates. Both texts likewise cite the same verse (Hos 4:6) when emphasizing that prelates should be knowledgeable. ${ }^{25}$ The markedly different handling of the same topic in both sermons supports the assumption that the sermons at the end of Ms 434 date from a time in which the practices surrounding appointments to ecclesiastical office and the immoral behaviour of many members of the clergy were viewed in a more openly critical light than had been the case at Zbraslav several decades previously, when Peter of Zittau was active. It is debatable whether the note in eleccione prelati in the bottom margin of fol. 176r does indeed reflect the occasion at which the sermon was to be given. A suitable occasion for sermons aimed at a clerical audience, criticizing various forms of immoral behaviour and giving examples from contemporary life, was a synod; during the last three decades of the 14th century the frequency of synods in Bohemia increased markedly in connection with the emergence of the reformist movement. ${ }^{26}$

As has been noted above, it is my opinion that the author of the last two sermons in Ms 434 was a member of the Zbraslav monastery who was writing in the second half (probably the final third) of the 14th century. We know of three such figures by name: In the 1370s, Jošt of Zbraslav wrote a text on the immaculate conception of the Virgin Mary. ${ }^{27}$ For a certain period Jan Štěkna $(\dagger 1407)$ was a member of the Zbraslav monastery; he was a lecturer at the Cistercian general college (becoming a Bachelor of Theology in 1391). Štěkna was a renowned preacher, known inter alia for his sermons

24 Cf. Ms 434, fol. 162 $\mathrm{v}^{\mathrm{b}}-163 \mathrm{r}^{\mathrm{a}}$ : Primus gradus, quo ascenderunt isti ad tronum dignitatis apostolice, est eleccio canonica. Cristus enim hos per se ipsum elegit, non per hominem sicut prelati symonici, qui dant pecuniam, nec per sortem sicut Mathias. Sed Cristus Petrum elegit Luce VI: Elegit XII, quos et | apostolos nominavit. Hoc fecit in terra. Paulum de celis elegit, quando eum prostravit et dixit: Vas eleccionis est iste etc. Nec ingesserunt se, sicut faciunt ambiciosi, Hebreorum V: Nec quisquam sumat sibi honorem, sed qui vocatur tamquam Aaron.

25 Cf. Posuit Deus hominem $\S 17$, Ms 434, fol. 163r $\mathrm{r}^{\mathrm{b}}$ : Dignum est, ut prelati habeant scienciam, quia dicit per Osee IIII: Quia tu repulisti scienciam, repellam te, ne sacerdocio fungaris michi.

26 Cf. Hledíková (2002: p. 150). For information on the Prague synods cf. also Polc \& Hledíková (2002).

27 This work has survived in a manuscript held at the Prague Castle Archive (APH), sig. D LXXII; cf. Patera \& Podlaha (1910: pp. 380-381, Nr. 638); Kadlec (1995: pp. 147, 152). 
at Prague's Bethlehem Chapel, and in 1400 he became a professor at the university in Krakow. ${ }^{28}$ Probably the most important writer who was active at the Zbraslav monastery during the immediate pre-Hussite period was Matouš of Zbraslav (Matthäus von Königsaal, known as Steynhus), who (like Štěkna) preached at various locations (in the Zbraslav monastery, at the university, and later at the Council of Constance) ${ }^{29}$ as well as being a teacher at the Cistercian general college. However, in 1411 circumstances forced him to leave and seek refuge (along with other monks from Zbraslav) in the Altzelle monastery, where he remained as a teacher of theology until his death in $1427 .{ }^{30}$ Unfortunately, no works by these three scholars have yet been published, with the exception of excerpts from the Constance sermons given by Matouš of Zbraslav; ${ }^{31}$ nevertheless, the two final sermons in Ms 434 are not listed among the incipits of texts attributed to the three authors. Because it has not been possible to identify the sermons Ingredere, benedicte Domini and Posuit Deus hominem with other sermons registered in the Schneyer Repertorium for the period 1350-1500, ${ }^{32}$ they must - until a comparative text analysis proves otherwise be considered to be the works of an unknown preacher.

$\begin{array}{ll}\text { Abbreviations } \\ \text { add. } & \text { additum } \\ \text { corr. } & \text { correctum } \\ \text { m. d. } & \text { margine dextro } \\ \text { m. s. } & \text { margine sinistro } \\ \text { m. sup. } & \text { margine superiore } \\ \text { L } & \text { Ms 434, Universitätsbibliothek Leipzig } \\ \text { PL } & \text { Patrologia Latina } \\ \text { <> } & \text { addendum }\end{array}$

\section{Bibliography}

\section{Primary sources}

Adriaen, M. (Ed.). (1985). S. Gregorii Magni Moralia in Iob libri XXIII-XXXV. Turnhout: Brepols. Atzert, C. (Ed.). (1963). Marcus Tullius Cicero: De officiis (4. ed.). Leipzig: Teubner.

28 On the literary work of Jan Štěkna cf. Kadlec (1966: pp. 102-104); on his activities in general cf. Siemiątkowska (1965).

29 A recent analysis of Matouš's sermon at the Council of Constance is given in Soukup (2014: pp. 182-187).

30 On the life and works of Matouš of Zbraslav cf. Kadlec (1966: pp. 104-106); Lauterer (1964; 1966; 1967).

31 Excerpts were published by Mansi (1785: pp. 908-910), Finke \& Hollnsteiner (1923: pp. 497-498). I found no marked similarities between these excerpts and the sermons in Ms 434.

32 Cf. Repertorium der lateinischen Sermones des Mittelalters für die Zeit von 1350-1500 von Johannes Baptist Schneyer. Herausgegeben von Ludwig Hödl und Wendelin Knoch. [Available via the website of Masaryk University, Brno, http://www.phil.muni.cz/wlap/; accessed 29. 8. 2016]. 
Baehrens, E. (Ed.). (1881). Disticha vel dicta Catonis. In Poetae Latini minores (Vol. 3; pp. 214-236). Lipsiae: Teubner.

Emler, J. (Ed.). (1884). Petra Žitavského Kronika Zbraslavská. In Fontes rerum Bohemicarum (Vol. IV; pp. 3-337). Praha: nákladem nadání Františka Palackého.

Finke, H., \& Hollnsteiner, J. (Eds.). (1923). Acta Concilii Constanciensis (Vol. 2). Münster: Regensberg.

Gryson, R., \& Weber, R. (Eds.). (1994). Biblia sacra iuxta Vulgatam versionem (4. ed.). Stuttgart: Deutsche Bibelgesellschaft.

Halporn, J. W. (Ed.). (1993). Cassiodorus: De anima. In Cassiodorus: Variarum libri XII. De anima (CCSL, 96; pp. 534-575). Turnhout: Brepols.

Hamesse, J. (Ed.). (1974). Les Auctoritates Aristotelis. Un florilège médiéval. Etude historique et édition critique. Louvain: Publ. Univ.

Hilberg, I. (Ed.). (1996). Hieronymus: Epistulae (Vol. I; CSEL, 54). Vindobonae: VÖAW.

Leclercq, J., Talbot, C. H., \& Rochais, H. M. (Eds.). (1957-1958). Bernardus Claraevallensis: Sermones super Cantica canticorum (S. Bernardi opera, 1-2). Roma: Ed. Cistercienses.

Leclercq, J., \& Rochais, H. M. (Eds.). (1963). Bernardus Claraevallensis: Tractatus et opuscula (S. Bernardi opera, 3). Roma: Ed. Cistercienses.

Leclercq, J., \& Rochais, H. M. (Eds.). (1966). Bernardus Claraevallensis: Sermones (Vol. I; S. Bernardi opera, 4). Roma: Ed. Cistercienses.

Leclercq, J., \& Rochais, H. M. (Eds.). (1968). Bernardus Claraevallensis: Sermones (Vol. II; S. Bernardi opera, 5). Roma: Ed. Cistercienses.

Leclercq, J., \& Rochais, H. M. (Eds.). (1974-1977). Bernardus Claraevallensis: Epistulae (S. Bernardi opera, 7-8). Roma: Ed. Cistercienses.

Mansi, G. D. (1785). Sacrorum conciliorum nova et amplissima collectio (Vol. 28). Florentiae: Zatta (reprint Paris 1903).

Migne, J. P. (Ed.). (1841). Augustinus: Sermones. In PL, 38. Parisiis: Migne.

Migne, J. P. (Ed.). (1854). Ernaldus Bonaevallis: De operibus sex dierum. In PL, 189 (pp. 15151570). Parisiis: Migne.

Migne, J. P. (Ed.). (1855a). Petrus Lombardus: Collectanea in omnes Pauli apostoli epistolas. In PL, 191 (1297-1696). Parisiis: Migne; PL, 192 (pp. 9-250). Parisiis: Migne.

Migne, J. P. (Ed.). (1855b). Alanus ab Insulis: Summa de arte praedicatoria. In PL, 210 (pp. 109196). Parisiis: Migne.

Migne, J. P. (Ed.). (1855c). Innocentius III: Libellus de eleemosyna. In PL, 217 (pp. 745-762). Parisiis: Migne.

Migne, J. P. (Ed.). (1857). Alcherus Claraevallensis (pseudo-Augustinus): De spiritu et anima. In PL, 40 (pp. 779-832). Parisiis: Migne.

Minio-Paluello, L. (Ed.). (1966). Porphyrius secundum translationem quam fecit Boethius. In Aristoteles Latinus (Vol. I, 6-7; pp. 5-31). Leiden: Brill.

Nechutová, J. (Ed.). (1999). Formula ad edificacionem fratris et monachi devoti v rukopisech Rakouské národní knihovny ve Vídni. Listy filologické, 122, 176-193.

Rochais, H. M. (Ed.). (1957). Defensor Locogiacensis: Liber scintillarum (CCSL, 117; pp. 2-234). Turnhout: Brepols.

Rusch, A. (Ed.). (1480/1481). Biblia cum glossa ordinaria Walafridi Strabonis aliorumque et interlineari 
Anselmi Laudunensis. Strasbourg: Adolf Rusch pro Antonio Koberger. [Retrieved 27. 9. 2016 from http://glossae.net].

Seyfarth, J. (Ed.). (1990). Speculum virginum (CCCM, 5). Turnhout: Brepols.

Vidmanová, A. (Ed.). (1998). Báseň De omni statu mundi. Listy filologické, 111, 88-94.

Waddell, Ch. (Ed.). (2007). The Primitive Cistercian Breviary (Staatsbibliothek zu Berlin, Preussischer Kulturbesitz, Ms. Lat. oct. 402) with Variants from the Bernardine Cistercian Breviary. Fribourg: Academic Press.

Walther, H. (Ed.). (1963-1967). Proverbia sententiaeque Latinitatis medii aevi. Lateinische Sprichwörter und Sentenzen des Mittelalters in alphabetischer Anordnung (Vol. I-V; Carmina medii aevi posterioris latina, II, 1-5). Göttingen: Vandenhoeck \& Ruprecht.

Warner, G. F. (Ed.). (1891). Giraldus Cambrensis: De principis instructione liber (Giraldi Cambrensis opera, 8). London: Longman.

\section{Secondary sources}

d'Avray, D. L. (1996). Sermons after 1200. In F. A. C. Mantello, \& A. G. Rigg (Eds.), Medieval Latin. An Introduction and Bibliographical Guide (pp. 662-669). Washington D. C.: Catholic University of America Press (reprint 1999).

Bériou, N. (2000). Les sermons latins après 1200. In B. M. Kienzle (Ed.), The Sermon (pp. 363-447). Turnhout: Brepols.

Bláhová, M. (2006). Dílna středověkého historika (Způsob práce Petra Žitavského). In A. Barciak, \& W. Iwańczak (Eds.), Piśmiennictwo Czech i Polski w średniowieczu we wczesnej epoce nowożytnej (pp. 11-33). Katowice: Wydawn. Uniwersytetu Śląskiego.

Briscoe, M. G. (1992). Artes praedicandi. In M. G. Briscoe, \& B. H. Jaye, Artes praedicandi. Artes orandi (pp. 7-76). Turnhout: Brepols.

Caplan, H. (1929). The Four Senses of Scriptural Interpretation and the Mediaeval Theory of Preaching. Speculum, 4, 282-290.

Charvátová, K. (2002). Dějiny cisterckého řádu v Čechách 1142-1420, II: Kláštery založené ve 13. a 14. století. Praha: Karolinum.

Dobschütz, E. von (1921). Vom vierfachen Schriftsinn. Die Geschichte einer Theorie. In HarnackEhrung. Festschrift Adolf von Harnack z. 70. Geburtstag (pp. 1-13). Leipzig: J. C. Hinrich.

Gerwing, M. (1986). Malogranatum oder der dreifache Weg zur Vollkommenheit. Ein Beitrag zur Spiritualität des Spätmittelalters. München: Oldenbourg.

Gerwing, M. (2004). „...state in fide vera, viriliter agite, omnia vestra in caritate fiant“. Zum dreifachen Weg im „Malogranatum“. In M. Derwich, \& M. Staub (Eds.), Die „Neue Frömmigkeit“ in Europa im Spätmittelalter (pp. 85-110). Göttingen: Vandenhoeck und Ruprecht.

Helssig, R. (1995). Die lateinischen und deutschen Handschriften der Universitäts-Bibliothek Leipzig, I: Die theologischen Handschriften, 1 (Ms 1-500) (Katalog der Handschriften der UniversitätsBibliothek Leipzig, IV). Wiesbaden: Harrassowitz (unveränderter Nachdruck der Auflage 1926).

Hledíková, Z. (2013). Peter von Zittau: das Beispiel des Autographs einer schöpferischen Persönlichkeit des 14. Jahrhunderts und Möglichkeiten der Autographenatlanten. In N. Golob (Ed.), 
Medieval autograph manuscripts. Proceedings of the XVIIth Colloquium of the Comité International de Paléographie Latine, held in Ljubljana, 7-10 September 2010 (pp. 163-180). Turnhout: Brepols.

Kadlec, J. (1966). Řeholní generální studia při Karlově univerzitě v době předhusitské. Acta Universitatis Carolinae Pragensis - Historia Universitatis Carolinae Pragensis, VI, fasc. 2, 95-107.

Kadlec, J. (1995). Teologická fakulta. In M. Svatoš (Ed.), Dějiny univerzity Karlovy I (1347/8-1622) (pp. 135-161). Praha: Karolinum.

Kienzle, B. M. (2000). The Twelfth-Century Monastic Sermon. In B. M. Kienzle (Ed.), The Sermon (pp. 271-323). Turnhout: Brepols.

Lauterer, K. (1964). Matthäus von Königssaal († 1427). Lebenslauf und Schrifttum. Cistercienserchronik, 71, 93-109.

Lauterer, K. (1966). Der Hymnenkommentar Matthäus' von Königssaal. Cistercienserchronik, 73, 33-43, 71-75.

Lauterer, K. (1967). Matthäus von Königssaal als Theologe. Cistercienserchronik, 74, 121-141, 170180.

Loserth, J. (1881). Die geistlichen Schriften Peters von Zittau. Sitzungsberichte der Akademie der Wissenschaften zu Wien, phil.-hist. Klasse, 98, 379-404.

Lubac, H. de (1959-1964). Exégèse médiévale. Les quatre sens de l'écriture (Vol. I, II). Paris: Aubier.

Mráz, M. (1970). Porfyriův Úvod k Aristotelovým Kategoriím. Filozofický časopis, 18, 971-987.

Muessig, C. (1998). What is Medieval Monastic Preaching? An Introduction. In C. Muessig (Ed.), Medieval Monastic Preaching (pp. 3-16). Leiden-Boston-Köln: Brill.

Patera, A., \& Podlaha, A. (1910). Soupis rukopisů knihovny metropolitni kapituly pražské (Vol. I). Praha: nákladem Čes. Akademie věd a umění.

Polc, J. V. (1994). Kapitoly z církevního života Čech podle předhusitského zákonodárství. In Z. Hledíková (Ed.), Pražské arcibiskupstvi 1344-1994. Sbornik statí o jeho pưsobeni a významu v české zemi (pp. 30-57). Praha: Zvon.

Polc, J. V., \& Hledíková, Z. (2002). Pražské synody a koncily předhusitské doby. Praha: Karolinum.

Pumprová, A. (2006a). Die Predigten des Peter von Zittau. Wo, vor wem und von wem sind sie gepredigt worden? In J. Nechutová, \& I. Radová (Eds.), Laetae segetes. Griechische und lateinische Studien an der Masaryk Universität und Universität Wien (pp. 98-110). Brno: Masarykova univerzita.

Pumprová, A. (2006b). Sermones in festivitatibus summis secundum ordinem Cysterciensem in capitulis faciendi. K formě dochování kázání Petra Žitavského. In H. Krmíčková, A. Pumprová, D. Růžičková, \& L. Švanda (Eds.), Querite primum regnum Dei. Sbornik př́spěvků k poctě Jany Nechutové (pp. 241-252). Brno: Matice moravská.

Pumprová, A. (2012). Svědectví autografu o práci Petra Žitavského s textem Zbraslavské kroniky. Časopis Matice moravské, 131, 239-263.

Schneyer, J. H. (1972). Repertorium der lateinischen Sermones des Mittelalters für die Zeit von 1150-1350 (Vol. IV; 2. ed.). Münster: Aschendorff.

Siemiątkowska, Z. (1965). Jan Sczekna. Materiaty $i$ studia Zaktadu historii filozofii starożytnej $i$ średniowiecznej, 5, 34-75.

Smalley, B. (1931). Stephen Langton and the Four Senses of Scripture. Speculum, 6, 60-76.

Soukup, P. (2014). Die böhmischen Konzilsteilnehmer zwischen Häresiebekämpfung und Kirchenreform. Die Konstanzer Predigten von Mauritius Rvačka, Stephan von Páleč und Matthäus von 
Königsaal. In G. Signori, \& B. Studt (Eds.), Das Konstanzer Konzil als europäisches Ereignis: Begegnungen, Medien und Rituale (pp. 173-217). Ostfildern: Thorbecke.

Doc. Mgr. Anna Pumprová, Ph.D. / anna.pumprova@osu.cz

Department of Latin Language and Culture

Vivarium - Centre for Research in Medieval Society and Culture

University of Ostrava, Faculty of Philosophy

Reální 5, 70103 Ostrava, Czech Republic 


\section{Editio}

${ }^{1}\left(\mid 173 \mathrm{r}^{\mathrm{a}}\right)$ Exhortacio ad bonum

Ingredere, ${ }^{2}$ benedicte Domini, cur foris stas? Preparavi domum, Genesis XXIIII.

1. Verba proposita, que Laban plus per infusionem Sancti Spiritus quam revelacione carnis proprie et sangwinis informatus sub typo Cristi ad nuncium Abrahe pro sui filii Ysaac coniugio delegatum sacra docet Pagina protulisse, aptissime hiis, qui ob amoris divini dulcedinem exulant natalis patrie, id est fomitem carnalis concupiscencie, ${ }^{3}$ que adversus spiritum militat, deserentes, ut ipsorum animam dulcibus veri Sponsi copulent amplexibus, interne devocionis contemplacionibus hospicio pii pectoris sunt puris affectibus laborantes, poterunt convenire. Hii sunt, qui non solum filium, ${ }^{4}$ id est oblectamenta exterioris affluencie, cum Abraham immolant, verum eciam se ipsos in sui tota corporis substancia Domino offerunt, benediccionem ${ }^{5}$ et misericordiam a Deo suscipiunt, que infinities stellarum ${ }^{6}$ celi et arene maris numerum exuperant. Hii sunt eciam, quorum nomen protelabitur, libro vite intitulabitur, qui eciam inmundiciis mundi illecebras parvipendunt, summo Patri religiose militare cupiunt sub vita et regula a sanctis patribus constituta.

2. Unicuique igitur religioso olim Deus loquens per servos suos prophetas per verba de futuro sermonem dictum proposuit. Nunc autem verbis huius consonis plus de presenti unumquemque religiosum, qui est de peculiari suo populo, quem translatum de Babylone presentis miserie Dominus promittit sublimari in celestem Ierusalem, alloquitur blandus Consolator dicens Matthei XI: Venite ${ }^{7}$ ad me omnes, qui laboratis et onerati estis et ego reficiam vos. Ille ergo, qui sue pietatis thesarum ${ }^{8}$ apperuit, in signum largitatis et amoris manibus, latere et pedibus perforari voluit, viam asperam et multum celicam sua ascensionis $\left(\mid 173 \mathrm{r}^{\mathrm{b}}\right)$ gloria planavit tibi et coluit, hodie et omni tempore innixus ${ }^{9}$ scale sanctitatis apparuit super te, opus manuum suarum, respiciens, hostium celi apperiens, te ad sequendum se ut aquila pullum, pater filium exhortando clamat dicens: Ingredere, benedicte Domini, cur ${ }^{10}$ foris stas? Preparavi domum.

3. Sciendum igitur: Aliquis fore benedictus in tribus cognoscitur. Primo si sit per Deum vocatus, sicut legimus Exodi III, Moysi, cum $^{11}$ minasset gregem suum ad interiora deserti, apparuit Dominus in flamma dicens sibi: Veni, mittam te. Mirum valde est, cum divina

$1 \quad$ m. sup. alia manu add.: Sancti spiritus assit nobis gracia.

2 Gn 24, 31.

3 carnalis ... spiritum: cf. Gal 5, 17.

4 filium ... immolant: $c f$. Gn 22, 1-14.

5 benediccionem ... suscipiunt: cf. Ps 23, 5.

6 stellarum ... maris: cf. Gn 22, 17; Ier 33, 22; Dn 3, 36.

7 Mt 11, 28.

8 thesaurum apperuit: cf. Dt 28, 12; Ier 50, 25.

9 innixus scale: $c f$. Gn 28, 13.

10 corr. $e$ tui $m$. $d$.

11 Ex 3, 1.2.10. 
virtus nullius loci circumferentia sit circumscripta, quare Dominus Moysi dicens tantum in interiori loco deserti vocaverit. Similiter cum Dominus sibi loqui voluit, nube ipsum semper circumdederit. Nonne poterat hec facere in tumultibus populi et in luce splendoris clarissimi? Certe potuit. Cepit ergo Dominus hec facere docere nos cupiens, ut qui sue vocacionis ${ }^{12}$ consolacionisque fieri volumus participes, a mundo et pompis eius nostros oculos abstrahamus et interioribus mentis pure cogitacionibus in ${ }^{13}$ terra deserta et invia sic in sancto et mundo corde appareamus, ut virtutem et gloriam Domini in terra vivencium videre valeamus.

4. Unde nos ab occupacionibus revocans exterioribus beatus pater noster Bernhardus sic informat animam meditari: $O^{14}$ sancta anima, sola esto, ut soli Creatori tuo serves te ipsam, quem tibi ex omnibus elegisti. Fuge forum publicum, fuge et ipsos domesticos, secede ab amicis et intimis! An nescis te verecundum habere sponsum, et qui nequaquam velit indulgere suam presenciam ceteris presentibus? Solus es, si non communia cogitas, si non affectas presencia, si despicis, quod multi suscipiunt. Sic eciam Tullius scribit: Numquam ${ }^{15}$ fui solus, quando fui solus, et numquam ociosus, quando fui ociosus; numquam fui solus in iocundis meditacionibus, quando fui solus ab amicorum allocucionibus, et numquam ociosus a labore studii, $\left(\mid 173 \mathrm{v}^{\mathrm{a}}\right)$ quando fui ociosus manuali non deditus operi. Utinam si huius gentilis ocium eciam nostro ocio sequeremur!

5. Secundo requiritur, quod sit cum erudicione propria utili a Domino increpatus, quem $^{16}$ enim diligit Dominus, corripit. Unde Ieremie I: Noli ${ }^{17}$ dicere, quia puer ego sum, ecce increpacio, sed increpacionis istius utilitas subditur: ne timeas, ecce confidencia, ego tecum sum, ecce Dei presencia, et tetigit os meum, ecce infuse sciencie eloquencia.

6. Tercio requiritur, quod sit a Domino sublimatus, propter hoc subditur: Ecce ${ }^{18}$ constitui te super gentes et super regna, gentes corrigendas et regnorum celestium aulas possidendas, et adhuc constitui te, ut evellas radicem superbie, destruas fomitem invidie, disperdas rancorem rixe et ire et dissipes omnem structuram criminum et edifices in corde pio humilitatis fundamentum solidum, in quo plantes turrim ex ${ }^{19}$ quadratis lapidibus, id est quatuor virtutibus cardinalibus, scilicet iusticia, temperancia, fortitudo, prudencia, et apposito cemento karitatis, ${ }^{20}$ que omnia sustinet, fidei, que omnia potest, spei, que omnia sperat, ita quod talis turris fortitudinis extructa virtutibus tuo corde fixa culmen celi penetret, mentem elevet et cordis oculos sedentem ${ }^{21}$ super alas cherubin tersis cunctis maculis faciat contemplari.

12 vocacionis ... participes: $c f . H b r 3,1$.

13 in ... videre: cf. Ps 62, 3; 26, 13.

14 Bernardus Claraevallensis, Sermones super Cantica canticorum 40, 4 (Leclercq - Talbot - Rochais [eds.] 19571958: 27).

15 numquam ... ociosus: Cicero, De officiis 3, 1, 1 (Atzert [ed.] 19634: 86).

$16 \operatorname{Prv} 3,12$.

17 Ier 1, 7.8.9.

18 Ier $1,10$.

19 Iud 1, 2.

20 karitatis ... sperat: cf. 1 Cor 13, 4.7.

21 sedentem ... cherubin: cf. Ez 11, 22. 
7. Sed quia ad predicacionis officium exequendum me insufficientem sencio, cum propheta dicere valeo: $A^{22}$ a a, Domine, nescio loqui, a propter remorsum consciencie, $a$ propter defectum sciencie, tercio $a$ propter inpedimentum eloquencie. Rogemus ergo veniam venie, Matrem misericordie, que sinum pietatis apperuit, ut de ${ }^{23}$ sue gracie plenitudine accipiant universi: captivi ${ }^{24}$ liberacionem, egri curacionem, peccator veniam, ut michi bonitatem contra lesam conscienciam, disciplinam contra ineloquenciam, scienciam contra ignoranciam me doceat, ut aliquid ad suam laudem et eius dulcis Filii gloriam $\left(\mid 173 v^{b}\right)$ et nostram edificacionem loqui valeam, prout ad ipsam mittamus salutacionem angelicam dicendo: Ave, Maria.

8. Ingredere etc. In verbis istis in principio propositis secundum tria in distinccione benedicti a Domino prenotata, similiter quantum ad nostram aliqualem instruccionem, ut benediccionis graciam consequi mereamur, tria principaliter sunt notanda: primo graciosa Domini attraccio seu invitacio, quod tangitur ibi: Ingredere ${ }^{25}$ benedicte Domini, secundo tardantis invitati fructuosa redargucio seu increpacio, quod tangitur ibi: Cur foris stas?, tercio generosa possessionis eterne invitati preparacio, quod tangitur ibi: Preparavi domum.

9. In hoc, quod dicitur: ingredere, tangitur Dei Patris potencia. Ingredere enim verbum inperii est, inperans autem potencia predicta se demonstrat. Et vere potens est Deus Pater, cuius velle est posse facere et factum esse, factum esse, quia ${ }^{26}$ dixit et facta sunt, mandavit et creata sunt universa. Et vere Patris est, $i n^{27}$ cuius dicione ${ }^{28}$ cuncta sunt posita, et non est, qui eius possit resistere voluntati, qui montes ${ }^{29}$ ponderat, terram palmo concludit. Et ne tantam potenciam sequi putetur crudelitas, apte subiungitur magna benignitas, cum dicitur <benedicte>, benedictos vocans paterne allicit et invitat. Ecce quomodo nos miserator ${ }^{30}$ et misericors Dominus prevenit ${ }^{31}$ in benediccionibus dulcedinis!

10. In hoc, quod dicitur: preparavi domum, tangitur Filii Dei profunda sapiencia. Sapientis $^{32}$ enim est ordinare et non ordinari, ut dicit Philosophus. Ipse autem est, qui preparat $^{33}$ et ordinat locum mansionis in celis universis, qui ${ }^{34}$ ambulant in viis eius, qui ${ }^{35}$ scrutantur testimonia eius in toto corde exquirentes. Unde in ewangelio loquitur Iohannis

22 Ier $1,6$.

23 de ... universi: cf. Io $1,16$.

24 corr. $e$ captivis $L$.

25 ingrede $L$.

26 Ps 32, 9.

27 Responsorium „Domine rex omnipotens“ (Waddell [ed.] 2007: 1174², 378).

28 indiccione $L$.

29 montes ... palmo: cf. Is 40, 12.

30 Ps 102, 8; 144, 8.

31 prevenit ... dulcedinis: cf. Ps 20, 4.

32 Auctoritates Aristotelis 1, 13 (Hamesse [ed.] 1974: 116).

33 preparat ... locum: cf. Ioh 14, 3.

34 Ps 127, 1.

35 Ps 118, 2. 
XIIII discipulis: Vado ${ }^{36}$ parare vobis locum, locum, inquam, patrie ${ }^{37}$ celestis, in quo mansio est secura continens totum, quod delectat, plena diviciis, ${ }^{38}$ superhabundans deliciis, cuius esca non aggravat stomachum, non gignit fastidium, omne, quod in ea sumitur, (|174r $\left.\mathrm{r}^{\mathrm{a}}\right)$ suave est et iocundum. Beati, ${ }^{39}$ qui habitant in domo illa, Domine, ubi ${ }^{40}$ melior est dies una super milia! Certe eligendum est unicuique abiectum $^{41}$ pocius esse in domo illa quam habitare in tabernaculis peccatorum. Beati vere sunt, qui domus huius civitatis celestis Ierusalem, cuius custodiam apostolorum et angelorum tenet exercitus et per cuius vicos ab universis martyribus, confessoribus et virginibus dicitur allelluia, concives esse per invitacionem celestium civium meruerunt!

11. In hoc autem, quod dicitur: cur foris stas, tangitur Spiritus sancti clementis bonitatis excellencia, cuius proprium est homines ad bonum corrigere. Ipse enim Dominus dicit Iohannis VII: Cum $^{42}$ venerit Paraclitus, Spiritus veritatis, ille arguet mundum de peccato et de iudicio et de iusticia. Et bene dicitur clementis bonitas, quia ipse Spiritus sanctus est principium amoris, unde in igne ${ }^{43}$ discipulis apparuit. Ipse abieccio erroris, unde propheta: Spiritus $^{44}$ tuus deducet me in terram rectam, scilicet terram vivencium. Ipse est principium recreacionis, unde Davit solacio divino destitutus in spiritu clamavit: Emitte ${ }^{45}$ Spiritum tuum et creabuntur. Non enim creari poterat de novo, quod genitus fuerat et iam actu fuit ens, sed revocari voluit ad palacium, in quo gloria ${ }^{46}$ Domini fit in seculum. O quam dulcis est Spiritus tuus, Domine! Quo ${ }^{47}$ gustato necesse est desipere carnem; affectanti celestia terrena non $^{48}$ sapiunt, eternis inhianti fastidio sunt transitoria. Cuius eciam benignitatem ostendens beatus Bernhardus, quam expertus sine dubio fuerat, quando dixit: Benignus ${ }^{49}$ est Spiritus sapiencie, et non consuevit esse difficilis se invocantibus, qui sepe, antequam invocetur, dicit: Ecce assum. Idem: ${ }^{50}$ Omnis anima, que vel semel gustavit Spiritus sancti dulcem presenciam, inpossibile est, ut elapsum non toto corde desideret; immo omnis anima in spiritu ${ }^{51}$ ambulans sponsum vel in amplexu vel affectu mentali, eciam cum manducat et $\left(\mid 174 \mathrm{r}^{\mathrm{b}}\right)$ bibit, inpossibile est non habere.

36 Io $14,2$.

37 Cassiodorus, De anima 15, 90 (Halporn [ed.] 1993: 568).

38 iterum sub textu $L$.

39 Ps 83, 5.

40 Ps 83, 11.

41 Ps 83, 11.

42 Io $16,8.13$.

43 igne ... apparuit: cf. Act 2, 1-4.

44 Ps 142, 10.

45 Ps 103, 30.

46 Ps 103, 31.

47 Bernardus Claraevallensis, Epistulae 111, 3 (Leclercq-Rochais [eds.] 1974-1977: 285).

48 m. d.

49 Bernardus Claraevallensis, Sermones super Cantica canticorum 15, 1 (Leclercq - Talbot - Rochais [eds.]. 19571958: 82); Sap 1, 6.

50 non inveni.

51 spiritu ambulans: cf. Gal 5, 16.25. 
12. Circa primum membrum principale sciendum est, quod tria attrahunt, scilicet similitudinis conformitas, hinc est, quod alia eiusdem spiritu et homines eiusdem officii se magis diligant et aves similes similiter volant. Secundum est, quod attrahit, declivitas seu loci humilitas, unde ad loca humiliora fluunt aque, Psalmorum: Qui ${ }^{52}$ emittis fontes in convallibus. Tercium est caliditas, unde calor solis attrahit aquas in nubes. Per hec scilicet tria, per conformitatem, per humilitatem, per caliditatem, verus sol iusticie nos dignatus est attrahere.

13. Primo conformitate: Cum autem propter mandati divini transgressionem natura hominis sui status nobilis incurrisset mutacionem, facta est passibilis, corruptibilis, deputata eternis suppliciis nec per se poterat relevari. Deus, Dei Patris Filius, consubstancialis Patri et equalis, genitus ante secula, nobis condolens sine macula factus est homo nobis similis per omnia, particeps nostre fragilitatis, ut nos exules sue divinitatis tribueret esse participes. Ecce qui hominem prothoplastum ad $^{53}$ ymaginem et similitudinem fecerat suam tamquam ex exemplari exemplatum figurans, in fine seculorum in ennarrabili pietatis sue clemencia exemplar exemplatum, Deus homo dignatus est fieri. Ecce emisit ${ }^{54}$ manum suam de alto, ecce inclinavit ${ }^{55}$ celos et descendit, ecce visus ${ }^{56}$ est super terram et cum homibus conversatus est, ecce venit rex $x^{57}$ et legifer noster. De quo dicit apostolus Philippensium I: Formam ${ }^{58}$ servi accipiens in similitudinem hominum factus est homo. Unde in hoc verbo bene innuit apostolus, quod non sceptro regali, pomposo comitatu, sed rex humilium sub forma servi venerit similem tibi se volens fieri. Eya homo, leva ${ }^{59}$ oculos tuos et contemplare iocunditatem, que venit tibi a Domino! Videamus ergo et summa di/ligencia (174va) caveamus, ne illi nos dissimiles faciamus, qui se nobis fecit similem et nos sibi similes vult ut fiamus!

14. Similium autem via, vita et opera eadem dinoscuntur, in via ergo, vita et opere, quibus ambulavit et ambulando informavit, debemus cum sollicitudine laborare. Ipse autem ambulavit in via paciencie, vita innocencie et opere obediencie. In via paciencie Ysaie I, quia faciem ${ }^{60}$ suam non avertit ab increpantibus et conspuentibus in eum. Vita innocencie I Petri II: Non ${ }^{61}$ est inventus dolus in ore eius. In opere obediencie Philippensium II, quia factus $^{62}$ est pro nobis obediens usque ad mortem. Si igitur in hiis precessit signifer, sequatur scutifer, si dominus, sequatur servus, si rex, sequatur miles intrepidus.

52 Ps 103, 10.

53 ymaginem ... suam: cf. Gn 1, 26.

54 Ps 143, 7.

552 Sm 22, 10; Ps 143, 5.

56 Bar 3, 38.

57 Is 33, 22.

58 Phlp 2, 7.

59 Responsorium „Hierusalem, surge“(Waddell [ed.] 2007: 44, 113).

60 Is $50,6$.

611 Pt 2, 22.

62 Phil 2, 8. 
15. Studeamus ergo, dilectissimi fratres, in paciencia eum sequi. Unde si per prelatos de excessibus nostris corrigimur digne, corde gaudeamus non murmurando, non irascendo, non proterve resistendo, non $^{63}$ dedignemur verba nostri vicii correctoria, eciamsi a vilioribus, mansuete vel te excusando tamquam innocens vel accusando tamquam iustus, ${ }^{64}$ qui accusator est sui, responde et non discedat a tua memoria, qualiter Ihesus stabat ante presidem inclinata facie, et dum accusaretur, nichil respondit, dum male tractaretur, non ${ }^{65}$ apperuit os suum. Unde ibi est vera paciencia, ubi pura consciencia tribulacionibus ab impiis angustatur. Unde si nichil pateris, coronam paciencie non mereberis. Sis ergo paciens in despectu, pauper voluntarius in defectu, ut beatus Bernhardus ${ }^{66}$ nos informat. Ergo si insurgant ${ }^{67}$ in te testes iniqui et mentitur ${ }^{68}$ iniquitas sibi, dic in corde tuo: Pro hiis tribulacionibus credo $^{69}$ videre bona Domini in terra vivencium, ubi accipiam $^{70}$ bravium, et sic debebis cogitando: Viriliter ${ }^{71}$ age et confortetur cor tuum et sustine Dominum, et sic consolaciones ${ }^{72}$ eius, qui iuxta ${ }^{73}$ est hiis, qui tribulato sunt corde, letificabunt animam $\left(\mid 174 v^{b}\right)$ tuam.

16. Studeamus eciam secundo, dilectissimi cristiani, sequi vite innocencia, unde cum ipse venerit seculum iudicare per ignem, unusquisque nostrum secure dicere possit cum psalmista: Iudica ${ }^{74}$ me, Domine, quoniam ego in innocencia mea ingressus sum. Et nunc sic vivemus, ut tunc audacter allegare valeamus: Perambulabam ${ }^{75}$ in innocencia cordis mei, in medio domus mee. Non proponebam ante oculos meos rem iniustam, facientes prevaricaciones odivi. Non adhesit mihi cor pravum declinante a me maligno. Non cognoscebam detrahentem secreto proximo suo, hunc persequebar superbo oculo et insaciabili corde, cum hoc non edebam. Ista si feceris, que planissime propheta proposuit, vere innocens $^{76}$ eris et accipies ${ }^{77}$ benediccionem a Domino et misericordiam a Deo, salutari tuo, et Regem ${ }^{78}$ in decore suo videbunt oculi tui, in $^{79}$ quem eciam angeli desiderant prospicere, quem ${ }^{80}$ semel vidisse omnia est scivisse.

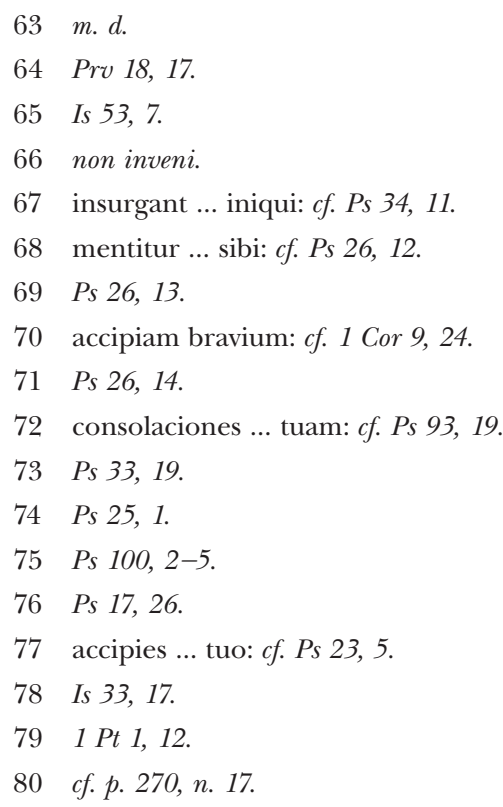


17. Studeamus tercio in operibus obediencie figere gressus nostros attendentes illud, quod dicitur libro Regum $\mathrm{I}^{\circ}$ capitulo $\mathrm{XV}^{\mathrm{o}}$ : Melior ${ }^{81}$ est obediencia quam victime, et illud apostoli Hebreorum XIII: Obedite ${ }^{82}$ prepositis vestris, et non tantum bonis, sed eciam discolis, et illud: Cristus ${ }^{83}$ factus est Patri ${ }^{84}$ pro nobis obediens usque ad mortem. Nos sine mora cum omni obediencia et reverencia nostris maioribus cervices nostrorum capitum offeramus, nam proculdubio quicumque religiosus suo prelato loco Dei voto se obediencie obligavit. Si non cum omni mansuetudine eius subicit se imperio, furtum, periurium coram Deo et mendacium perpetravit. Furtum est enim contraccio rei aliene invito domino, religiosus ergo quilibet, qui sui corporis et voluntatis poma suo prelato tribuit, si ipsa sibi invito domino usurpaverit, proculdubio fur ${ }^{85}$ est et latro, et omnis ${ }^{86}$ talis non habet partem in regno Cristi et Dei. Qui autem cum Cristo usque ad mortem fuerit obediens et cum psalmista dixerit: Paratum ${ }^{87}$ cor meum, Deus, paratum cor meum, illum $^{88}$ exaltabit et donabit illi nomen, quod est super omne nomen, quo res humane transitorie nominantur.

18. Secundo $\left(\mid 175 \mathrm{r}^{\mathrm{a}}\right)$ nos Dominus attrahit loci declivitate, id est vite sue, quo vixit, humilitate. Ecce fratres, quanta humilitas nostri Salvatoris, quod ille, qui est Deus ${ }^{89}$ fortis, homo factus est fragilis, incircumscriptibilis pannis strictis positus est in cunabulis, qui visus ${ }^{90}$ est sedere in solio, sedere ${ }^{91}$ voluit in asino. Quid ${ }^{92}$ ergo retribuemus Domino pro omnibus, que retribuet nobis? Nam pro nobis humiliatus ${ }^{93}$ est usquequaque. Certe timendum est, ne dives $^{94}$ velit fieri vilis vermiculus, pro quo Deus maiestatis et Dominus Sabaoth voluit pauper fieri, ut statim poneretur intus $i n^{95}$ presepio, cum ei non esset locus in diversorio. Non ergo nobis restat faciendum, qui pulvis ${ }^{96}$ sumus et cinis, aliud, nisi quod Cristi vestigia in humilitatis tramite consequamur. Ipsam enim commendando Bernhardus sic diffinit: Humilitas ${ }^{97}$ est regina virtutum, mors viciorum, nutrix discipline, radix sciencie, religionis vigor, virginitatis decor, Spiritus sancti receptaculum, Trinitatis hospicium. Et ipse eciam dicit super ewange-

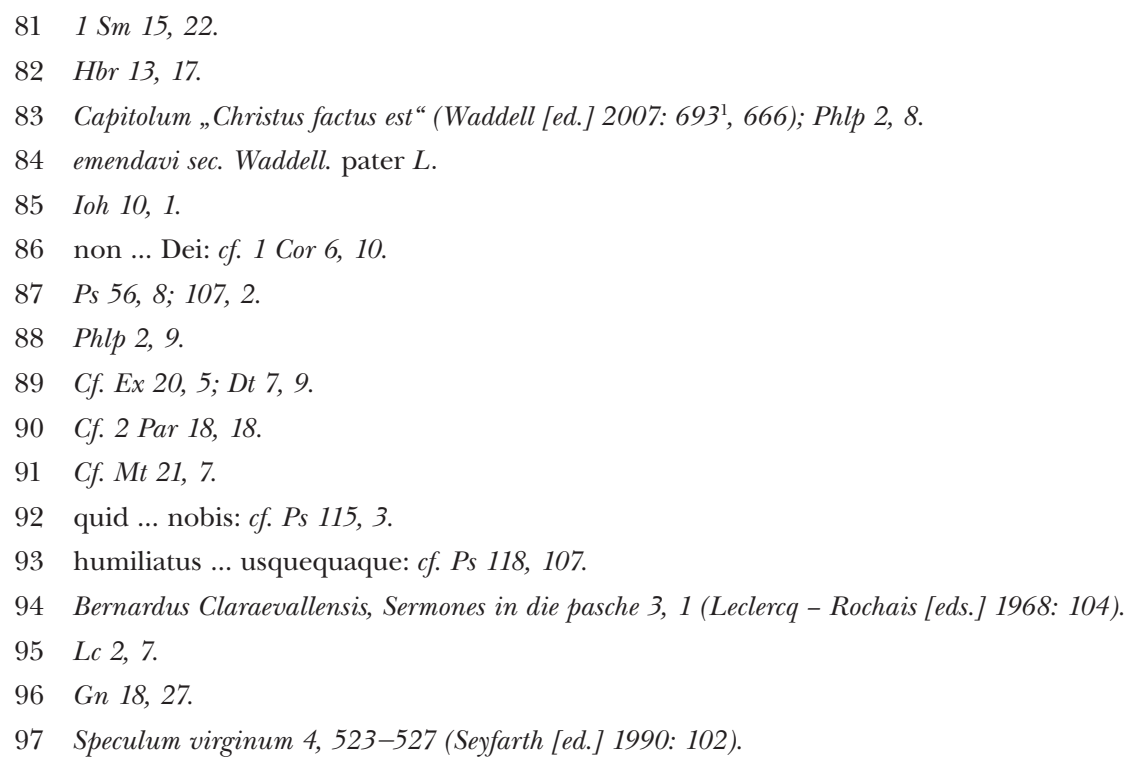


lium „Missus est angelus“: Nisi Maria Virgo ${ }^{98}$ humilitate prefulsisset, Dominum nullatenus concepisset. Illam ergo virtutum Reginam omni studio imitantes, ne superbia ${ }^{99}$ sub pannis humilitatis, quibus nos religiosi vestiti sumus, habitet, caveamus. Non enim congrueret, ut superbia hoc habitu et vestitu se palliet, quo involuta fuit humilitas et infancia Salvatoris.

19. Tercio Dominus nos attrahit caliditate, id est fervida karitate, Iohannis VI: Maiorem $^{100}$ enim karitatem nemo habet, ut animam suam quis ponat pro amicis suis. Vix ${ }^{101}$ pro iusto moritur quis, ipse autem pro nobis iniustis moriens fratres facit servos, amicos appellat inimicos, captivos heredes, exules facit reges. Et quia prior ${ }^{102}$ dilexit nos, non ${ }^{103}$ vult a nobis aliud quam diligi, quia ob aliud non amat, nisi ut ametur. Ergo ${ }^{104}$ cunctis renuncians affeccionibus fidelis anima tota incumbat eius amori. Et quantum karitas Cristi conferat diligenti, ostendit Bernhardus: Vere ${ }^{105}$ dulcis et suavis cibus $\left(\mid 175 \mathrm{r}^{\mathrm{b}}\right)$ est karitas, que fessos alleviat, debiles roborat, mestos letificat, iugum suave, onus facit leve. Caritas, ${ }^{106}$ ut hominem facilius vinceret, prius Deum superavit, vulneravit inpassibilem, ligavit insuperabilem, traxit incommutabilem, eternum effecit mortalem. O anima, si sine caritate esse non debes neque potes, cum illo te occupa, cuius memoria super ${ }^{107}$ mel et favum dulcis gutturi tuo! Si igitur hic est dilectus ${ }^{108}$ tuus, sponsus tuus, electus ex milibus, totus desiderabilis, si venerit ${ }^{109}$ et pulsaverit, manus ${ }^{110}$ per cancellos miserit clamans anime tue: „Soror ${ }^{111}$ mea, sponsa mea, columba mea, aperi michi“, responde: „Veniat ${ }^{112}$ dilectus meus in ortum suum et osculetur ${ }^{113}$ me osculo oris sui amoris dulcedinem instillando.“ Dic eciam: „O dilecte, ${ }^{114}$ tu michi et ego tibi, trahe $e^{115}$ me post te viam rectitudinis demonstrando, et cum inclinentur ${ }^{116}$ umbre vite,

98 Virgo ... concepisset: cf. Bernardus Claraevallensis, Homiliae super Missus est 1, 5 (Leclercq - Rochais [eds.] 1966: 18).

99 Bernardus Claraevallensis, Apologia ad Guillelmum abbatem 3 (Leclercq - Rochais [eds.] 1963: 83).

100 Io $15,13$.

$101 \mathrm{Rm} 5,7$.

1021 Io 4, 19 .

103 Bernardus Claraevallensis, Sermones super Cantica canticorum 83, 4 (Leclercq - Talbot - Rochais [eds.] 19571958: 301).

104 Alcherus Claraevallensis (pseudo-Augustinus), De spiritu et anima 36 (Migne [ed.] 1857: PL 40, col. 807).

105 Bernardus Claraevallensis, Liber de gradibus humilitatis et superbiae 3 (Leclercq - Rochais [eds.] 1963: 18).

106 Alanus ab Insulis, Summa de arte praedicatoria 20 (Migne [ed.] 1855b: PL 210, col. 152B); Innocentius III, Libellus de ellemosyna, encomium charitatis (Migne [ed.] 1855c: PL 217, col. 762).

107 super ... tuo: cf. Ps 18, 11; Ct 2, 3.

108 dilectus ... desiderabilis: $c f$. Ct 5, 10.16 .

109 Lc 12, 36.

110 manus...miserit: cf. Ct 5, 4.

111 Ct 5, 2 .

112 Ct 5, 1 .

113 Ct 1, 1.

114 dilecte ... tibi: $c f$. Ct 2, 16.

115 Ct 1, 3.

116 Ct 2, 17. 
qua habito in corpore, curram $^{117}$ tecum in odorem ungentorum tuorum tue maiestatis faciem sine termino contemplando.“

20. Circa secundum principale membrum est notandum, quod duplicem legimus argucionem, hominis scilicet et Dei, hominis ut apostolus Ephesiorum V: Nolite ${ }^{118}$ com- $^{-}$ municare operibus infructuosis, de secundo Psalmorum: Domine, ${ }^{119}$ ne in furore tuo arguas me. Primo quare et qualiter ab homine sit arguendum, dilectissimi, breviter videamus. Quinque autem de causis debet fieri proximi caritativa argucio: Primo, ut Deo precipienti obediamus, Matthei XVII: $S i^{120}$ peccaverit in te frater tuus, corripe eum etc. Secundo, ut peccatum in nobis evitare valeamus, Glossa super Mattheum XVIII: Ita ${ }^{121}$ peccat, qui viderit fratrem suum peccare et tacet, sicut qui peccanti non indulget.

$S i^{122}$ quis delinquit, ut Paulus apostolus inquit,

qui consentit ei, fit reus ipse rei.

Tercio, ut presentibus timorem incuciamus, apostolus: Peccantes ${ }^{123}$ coram hominibus arguite, ut ceteri timorem habeant. Quarto, ut ipsos ad amorem et bonum inducamus, Proverbiorum IX: Argue ${ }^{124}$ sapientem et diliget te. Quinto, ut graciam Domini et famam hominum racione exempli habe|amus, (175v ${ }^{\mathrm{a}}$ ) Proverbiorum XIIII: Qui ${ }^{125}$ arguunt, laudabuntur.

21. Nunc vide, qualiter sit proximus arguendus. Quinque modis fiat argucio: iuste, constanter, mansuete, dure, sapienter. Iuste, Glossa super Mattheum: Zelo ${ }^{126}$ iusticie sic corrigamus, ut peccanti viscera misericordie impendemus; timendum est ergo, ne ex odio quis corrigat. Constanter, ne iram vel odium correcti timeamus, Crisostomus: ${ }^{127}$ Melius est odium pati propter Deum quam amicicia frui propter proximum. Mansuete bonos, Psalmorum: Supervenit ${ }^{128}$ mansuetudo et corripiemur. Leo papa: Leniter ${ }^{129}$ castigatus reverenciam exhibet castiganti, asperitatis vero nimie increpacio nec correccionem recipit nec salutem. Dure malos, Tymothei ${ }^{130}$ I increpat eos dure, ut sint salvi. Tamen de hiis duobus dicit Gregorius: $\mathrm{Sit}^{131}$ amor non emolliens, rigor non exasperans, zelus non inmoderate feriens,

117 Ct 1, 3 .

118 Eph 5, 11.

119 Ps 37, 2.

120 Mt 18, 15.

121 Glossa ordinaria marg. ad Mt 18, 15 ad „Corripe“ (Rusch [ed.] IV, fol. $950 v^{\mathrm{b}}$ ).

122 Walther (1963-1967: 28993); cf. Rom. 1, 32; Cronica Aulae regiae I, 91 (Emler [ed.] 1884: 128B).

$1231 \operatorname{Tim} 5,20$.

$124 \operatorname{Prv} 9,8$.

$125 \operatorname{Prv} 24,25$.

126 Glossa ordinaria marg. ad Mt 18, 15 ad „Si peccaverit in te“(Rusch [ed.] IV, fol. 950vb).

127 non inveni.

128 Ps 89, 10.

129 Defensor Locogiacensis, Liber scintillarum 31, 21 (Rochais [ed.] 1957: 122).

130 cf. 1 Tim 5, 20.

131 Sit ... parcens: cf. Gregorius Magnus, Moralia in Iob 20, 5 (Adriaen [ed.] 1985: 1012). 
pietas plus ei parcens. Sapienter, Augustinus: Tunc ${ }^{132}$ secrete argue, cum te solo sciente, quis peccaverit, ne si publice argueris, non sis corrector criminis, sed proditor.

22. De secunda argucione, scilicet Dei, eciam aliqua videamus. Notandum, quod tripliciter arguit Dominus: in furore, in ira et equitate. In furore ${ }^{133}$ eternaliter dampnandos, ut dicit Glossa, in ira in purgatorio emendandos, illos castigans ${ }^{134}$ castigat Dominus, nec tamen morti tradit, in equitate presenti tempore constitutos, Ysaie XI: Arguet ${ }^{135}$ in equitate pro mansuetis terre. Illa appetit psalmista alias a se excludens, quando dicit: Domine, ${ }^{136}$ ne in furore tuo arguas me neque in ira tua corripias me. In furore Dominus dampnandos arguit de peccatis infidelitatis, cupiditatis, carnalitatis, superbie, ire, invidie et ceteris mortalibus. Et si vis scire, qualiter arguit, iam ostendam: arguet in die novissimo proponendo, assumendo, concludendo. Proponendo omnia bona, que ostendit nobis diviciis, potenciis, sciencias, corporis elegancias ostendendo, et dicet: Quid ${ }^{137}$ ultra debui facere et

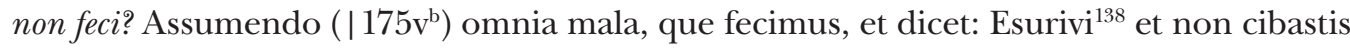
me, sitivi etc. Concludendo: Ite ${ }^{139}$ maledicti, in ignem eternum etc. Gregorius: Dominus proponet $^{140}$ legem, assumet transgressionem et concludet dampnacionem.

23. In ira Dominus arguet et purgatores purgandos de multis: de iusticia, quam non fecerunt, de iudicio, quod non timuerunt, de vanitatibus, quas commiserunt, de insipiencia, qua peccatum ignoraverunt, de verbis inutilibus, que protulerunt, de preceptis legis, que non impleverunt. In equitate arguit adhuc in corpore militantes flagellacione, consciencie remorsione, allocucione. Flagellacione in temporalibus, Thobie XII: Filii, ${ }^{141}$ noli negligere disciplinam Domini nec fatigeris, cum ab eo argueris. Consciencie remorsum (!), Psalmorum: Arguam ${ }^{142}$ te et statuam contra faciem tuam. Allocucione, Apokalypsis III: Ego, ${ }^{143}$ quos amo, arguo, et quos karitate nimia diligit, attrahit sibi miserans. Illud ergo verbum: cur foris stas, est piissime allocucionis correccio, et illa amicabili correccione gaudeas argui, si ab eo vis amari. Noli ergo foris stare in peccatis, sed ingrediaris ianuam pietatis virtutum vestibus decoratus!

24. Circa tercium principale membrum est notandum, quod preparacio domus fit tripliciter: quandoque preparat homo homini, quandoque homo Deo, quandoque Deus homini preparat domum. Dicitur preparare: Prima domus, quam parat homo homini, fit de lignis, lateribus et lapidibus materialibus et illa protegit nos pro tempore a caumatibus,

132 Petrus Lombardus, Collectanea in omnes Pauli apostoli epistolas, ad I Tim 5, 19, ad „adversus autem“ (Migne [ed.] 1855a: PL 192, 355D) cf. Augustinus, Sermones 82 (Migne [ed.] 1841: PL 38, 510).

133 furore ... emendandos: cf. Glossa ordinaria inter. ad Ps 37, 2 ad „O Domine“, „neque“ (Rusch [ed.] II, fol. 250r ).

134 castigans ... tradit: cf. Ps $117,18$.

135 Is 11, 4.

136 Ps 6, 2; 37, 2.

137 Is 5, 4.

138 esurivi ... sitivi: cf. Mt 25, 42.

139 Mt 25, 41.

140 apud Gregorium non inveni; Giraldus Cambrensis, De principis instructione 2, 7 (Warner [ed.] 1891: 172).

$141 \mathrm{Hbr} 12,5$.

142 Ps 49, 21.

143 Apc 3, 19 . 
a turbine et a pluvia. In illa letamur, movemur, comedimus, bibimus, fruimur voluptatibus. Sed quia homo ${ }^{144}$ natus de muliere brevi vivens tempore quasi flos egreditur et conteritur et fugit velud umbra, cum corpus sit limus et anima spiritus peregrinus, cum spiritus ${ }^{145}$ redit ad Dominum, qui dedit illum, consequens est, ut domus alia carni corporis construatur. Et quia terra ${ }^{146}$ est et in terram revertitur, in terra sibi merito domus alia preparatur. Unde psalmista: Sepulcra ${ }^{147}$ eorum domus illorum $\left(\mid 176 \mathrm{r}^{\mathrm{a}}\right)$ in eternum. Et in tali domo homo non comedit, sed qui prius comedit, comeditur a ranis et serpentibus. Nec ibi procumbens pro refrigerio moveri de loco ad locum vel de latere ad latus aliud et manus et pedes contrahere vel extendere ligatos sudario non poterit, sed hec ${ }^{148}$ requies eius in seculum seculi, ibi habitabit, quousque $i n^{149}$ voce tube canet angelus: Mortui, surgite et ad horrendum Domini iudicium de talentis ${ }^{150}$ traditis racionem facturi ${ }^{151}$ festinate! Tunc, sicut dicit Gregorius, virtutes ${ }^{152}$ celorum movebuntur, quid tunc ${ }^{153}$ nos miseri, qui cinis et pulvis sumus, facturi sumus? Ibi reges ${ }^{154}$ quondam potentes nudo latere palpitabunt, illic tribus ad tribum sua pectora percucient, illic argumenta ${ }^{155}$ Aristotelis vel Platonis nil valebunt, sola iusticia ibi iustum a morte liberabit. Ergo, fratres, nunc in tempore messis, quia regiones ${ }^{156}$ adhuc albe sunt ad messem, cum sapientibus ${ }^{157}$ virginibus bonorum operum oleum comparemus, ut veniente Sponso erepti de tam horrendo iudicio introire secum ad nupcias valeamus!

25. Secunda domus, quam facit homo Deo, est anime ad recipiendum influenciam divine gracie preparacio. Unde scriptum est I Regum VII: Preparate ${ }^{158}$ corda vestra Domino, et alibi: Anima ${ }^{159}$ iusti sedes est Dei, et alibi: Delicie ${ }^{160}$ mee esse cum filiis hominum. Unde Bernhardus: Unde ${ }^{161}$ tibi, o anima, tam inestimabilis gloria, ut eius ${ }^{162}$ sponsa merearis esse, in quem desiderant angeli prospicere? Unde tibi, ut Sponsus tuus sit, cuius pulcritudinem sol et luna mirantur, ad cuius nutum universa mutantur? Unde, karissimi fratres, vere expedit, ut tam

144 Iob 14, 1-2.

$145 \mathrm{Ecl} \mathrm{12,7.}$

$146 \mathrm{Ecl} \mathrm{3,} 20$.

147 Ps 48, 12.

148 Ps 131, 14.

149 Ps 46, 6.

150 talentis traditis: $c f$. Mt 25, 14-30.

151 iterum m.d.

152 Lc 21, 26.

153 cinis ... sumus: cf. Gn 18, 27.

154 Hieronymus, Epistulae 14, 11 (Hilberg [ed.] 1996: 61).

155 emendavi argumento $L$.

156 Io 4, 35.

157 sapientibus ... sponso: cf. Mt 25, 1-13.

$1581 \mathrm{Sm} 7,3$.

159 anima ... Dei: cf. Prv 12, 23 sec. VL.

$160 \operatorname{Pro} 8,31$.

161 Bernardus Claraevallensis, Sermones in dominica I post octavam Epiphaniae 2, 3 (Leclercq - Rochais [eds.] 1966: 321); 1 Petr 1, 12.

162 corr. $e$ cinis in textu $L$, eius $m . d$. 
egregio Sponso, qui delicias suas reputat nobiscum commorari, in anima nostra lectum, ubi $^{163}$ cubat, ubi requiescat in meridie, id est plenitudine leticie, omni spurcicie ${ }^{164}$ eiecta scoria omni virtutum floribus adornatum mente letissima faciamus, sicut legimus Canticorum III: Ferculum ${ }^{165}$ fecit sibi rex Salomon de lignis Libani. Collumpnas eius fecit (|176 $\left.\mathrm{r}^{\mathrm{b}}\right)$ argenteas, reclinatorium aureum, ascensum purpureum, media karitate constravit propter filias Iherusalem. Quod, fratres karissimi, quantum ad propositum et sic exponere possumus: Rex Salomon, id est Ihesus Cristus, qui est Salomon, id est sapiens, cuius $^{166}$ sapiencie non est numerus, fecit, id est fieri desiderat, in anima nostra sibi ferculum, id est lectum vel mansionem, de lignis Lybani, que sunt inputrescibilia, id est ex recto et ordinato appetitu racionali, qui est imputrescibilis et immortalis. Collumpnas, id est appetitum sensualem, fecit, id est fieri vult, argenteas, id est puram, non errantem - et bene dicit collumpnas, quia sicut collumpna supponitur edificio, sic appetitus sensiwus supponi debet intellectivo. Et fecit, id est fieri vult, reclinatorium aureum, id est quietem contemplacionis divine maiestatis, quam anima tunc sentit, cum nichil preter eum amat neque sentit, et ascensum purpureum, id est virtutem paciencie et humilitatis, nam hec virtutes veri sunt ascensus, per quem itur ad astra. Et constravit, id est consterni vult, omnia ista, id est omnes istas virtutes, media, id est in medio, vel media, id est mediante, id est fortissime, karitate, que est tamquam sal virtutum omnium aliarum, ut bene declarat apostolus: $S^{167}$ liguis loquar etc. Et illa karitas apponitur propter filias Ierusalem, id est propter celestis pacis visionem.

26. Tercia est domus, quam preparavit ${ }^{168}$ ab inicio mundi Dominus hominibus diligentibus se. Quam David conspiciens exclamavit: ${ }^{169}$ domum Domini letantes ibimus! Stantes ${ }^{170}$ erant pedes nostri in atriis tuis, Ierusalem. Hec est Ierusalem, ${ }^{171}$ civitas Regis eterni, quam ex adipe frumenti saciat et cum fluminis impetu letificat, ubi vera sacietas et affluencia summa, ubi sanctum convivium, ubi desiderabiles epule, ubi nullum fastidium, sed permanens gaudium.

Ad quod nos perducat Ihesus, Marie Filius, cui cum Patre et Spiritu sancto honor et gloria per omnia secula seculorum, amen.

Posuit Deus hominem in paradyso ${ }^{172}$

$\left(\mid 176 \mathrm{v}^{\mathrm{a}}\right)$ Posuit ${ }^{173}$ Deus hominem in paradyso voluptatis, ut operaretur et custodiret illum, Genesis I.

163 ubi ... meridie: $c f$. Ct 1, 6 .

164 spurtiticie $L$.

165 Ct 3, 9-10.

166 Ps 146, 5.

1671 Cor 13, 1.

168 preparavit ... se: cf. 1 Cor 2, 9.

169 Antiphona „In domum Domini“(Waddell [ed.] 2007: 4071, 190); cf. Ps 121, 1.

170 Ps 121, 2.

171 Bernardus Claraevallensis, Sermones in septuagesima 1, 3 (Leclercq - Rochais [eds.] 1966: 347); cf. Est 8, 15; Mt 5,35 .

172 sub textu alia manu: in eleccione prelati $L$.

173 Gn 2, 15. 
1. Secundum spiritalem huius verbi intelligenciam describitur institucio, qualitas et operacio vel officium prelatorum; a quo institui debeant, quales eos oporteat esse, quale officium debeant exercere: a Domino enim debent institui, homines debent esse, operari $^{174}$ debent et custodire. Que tria tanguntur per ordinem, cum dicitur: Posuit Deus hominem in paradyso voluptatis etc.

2. Paradysus voluptatis est militans ecclesia, spiritualibus voluptatibus exuberans et referta. Et signatur per illam terrestris paradysus, que ad litteram dicitur paradysus voluptatis propter tria: est enim aquis irrigua, fructu fecunda, situ amena. De primo Genesis II: Fluvius ${ }^{175}$ egrediebatur de loco etc. De secundo ibidem: Produxit ${ }^{176}$ Deus de humo omne lignum pulchrum visu etc. De tercio dicit Strabus, quod sic est in ${ }^{177}$ alto situs, quod pertingit usque ad globum lunarem. Inde est, quod aque diluvii illuc minime pertingebant. Ad huius terrestris paradysi similitudinem ecclesia militans est aquis habundans et irrigua in penitentibus, fructu fertilis et fecunda in proficientibus, situ delectabilis et amena in perfectis.

3. Dico, quod est aquis irrigua in penitentibus, ${ }^{178}$ in quo educit ${ }^{179}$ Deus aquam de petra, qui percussit petram, id est cordis duriciam, et fluxerunt aque lacrimarum, quia exitus ${ }^{180}$ aquarum deduxerunt oculi mei, quia non custodierunt legem Domini, ita quod possint dicere cum propheta: Lavabo ${ }^{181}$ per singulas noctes etc. Hee sunt aque expiacionis, quibus mundantur inmundi. Hee sunt aque refeccionis, quibus refocilantur sitibundi. Hecce sunt aque vive, quibus ${ }^{182}$ reviviscunt mortui peruncti. Sunt ergo hee aque expiacionis, quibus mundantur inmundi Numeri XIX, ubi precepit Dominus, quod inmundus ${ }^{183}$ aspergatur aqua expiacionis et sic mundabitur. Inmundi sunt peccatores, qui aqua expiacionis aspergi debeant, $\left(\mid 176 v^{b}\right)$ id est aqua lacrimarum, que ${ }^{184}$ est mundificans, ${ }^{185}$ unde dicitur lacrima quasi lavans crimina. Et bene precipit Dominus inmundum ista aqua aspergi, non totum intingi, quia non est ${ }^{186}$ istarum aquarum tanta habundancia, ut totus possit intingi, sufficit, si aspergatur. Unde aspersionem solam petebat propheta dicens: Asperges $^{187}$ me, Domine, ysopo etc.

174 corr. $e$ operari $L$.

175 Gn 2, 10.

176 Gn 2, 9.

177 Glossa ordinaria marg. ad Gn 2, 8 ad „Plantaverat autem Dominus“ (Rusch [ed.] I, fol. 11ra).

178 corr. $e$ presentibus $L$.

179 Ps 77, 16.20.

180 Ps 118, 136.

181 Ps 6, 7.

182 corr. $e$ qui $L$.

183 cf. Nm 19, 12-13.

184 corr. $e$ qui $L$.

185 emendavi mundificatam $L$.

186 m. $s$.

187 Ps 50, 9. 
4. Obturat dyabolus, quantum potest, fontes huius aque, ne possimus haurire. Quod significatum est in Iudit VII, ubi dicitur, quod posuit ${ }^{188}$ Holofernes custodes foncium, ut non haurirent filii Israel, et dabatur aqua populis ${ }^{189}$ in mensura. Fontes istarum aquarum sunt duo, scilicet recordacio peccatorum et timor suppliciorum, qui provocant hominem ad lacrimandum. Sed Holofernes istos fontes custodit, quia dyabolus, quantum potest, hominem avertit, ne cogitent de peccatis commissis nec de futuro iudicio ad timendum. Unde de peccatore dicitur: Auferunt ${ }^{190}$ iudicia tua a facie eius. Quia sic obturat dyabolus fontes istos, extrahitur populis aqua in mensura. Propter hec signanter dicit Dominus, quod inmundus debet aspergi aqua expiacionis, id est aqua lacrimarum, que hominem mundant et expiant.

5. Iterum sunt aque refeccionis, quibus refocilantur sitibunda. Unde et aquas refeccionis vocat eas propheta dicens: Super ${ }^{191}$ aquam refeccionis educavit me. Conversi peccatores educantur, donec crescant in virum perfectum super aquam refeccionis, id est super aquam lacrimarum, que in timore homines reficiunt. Unde et panis dicuntur: Fuerunt, ${ }^{192}$ inquit, michi lacrime mee panes die ac nocte. Non solum sunt cibus, sed sunt cibus et potus, Psalmorum: Cibabit ${ }^{193}$ nos pane lacrimarum etc. Recte ergo dicuntur lacrime aque refeccionis. Sed nota, quod non sunt panes ${ }^{194}$ canum, sed filiorum, nec inveniuntur ubique panes isti, sicut signatum habemus Genesis 36 de Abna, qui ${ }^{195}$ invenit aquas calidas in solitudine. Abna ${ }^{196}$ interpretatur gratificatus, qui penitentem signat, qui prius ingratus fuit per culpam, per penitenciam gratus efficitur. Iste invenit aquas calidas, scilicet lacrimarum, que igne contricionis calefiunt enim cor $\mid \mathrm{da}^{197}\left(177 \mathrm{r}^{\mathrm{a}}\right)$ Domino, ${ }^{198}$ propheta: Concaluit ${ }^{199}$ cor meum intra me etc. Ideo dyabolus quasi excatezizatus non audet accedere, quia in hiis aquis ${ }^{200}$ submergitur pharao cum exercitu suo. Sed nota, quod invenit aquas istas in solitudine, scilicet religionis, non, inveniuntur inter illos, qui tenent ${ }^{201}$ timpanum. Soli filii pane lacrimarum reficiuntur, ideo dicuntur aque refeccionis.

6. Sunt eciam aque irrigue, quibus infructuosi fecundantur, irrigantur, Deuteronomio $\mathrm{XI}$, ubi dicitur, quod $i^{202}$ terra Egypti in ortorum morem aque dicuntur irrigue iacto semine.

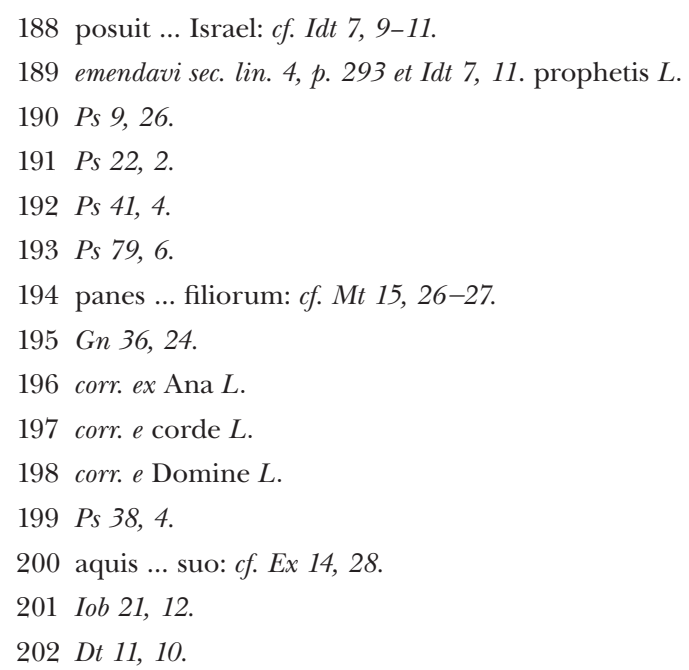


Terra Egypti, cor peccatoris, seritur ad irrigandum, scilicet cor aridum, et fecundandum. De irrigacione Ecclesiastici II: Rigabo ${ }^{203}$ ortum plantacionum. Iterum sunt aque vive, quibus semina bonorum operum, prius per peccatum mortificata, irrigata vivificantur, Genesis XXVI: Foderunt ${ }^{204}$ in torrente et repererunt aquam vivam. Iohannis IIII: Petisses ${ }^{205}$ ab eo et dedisset tibi aquam vivam. Hoc igitur quadruplici genere irrigatur paradysus spiritualis in peccatoribus.

7. Est iterum fructu fertilis et fecunda in proficientibus, qui ad modum arboris botros proferunt, florent et fructus afferunt: botros proferunt in cogitacione boni, florent in eius amore, fructum afferunt in operacione. Unde et arbori fructifere ${ }^{206}$ comparantur, ubi dicitur per prophetam Ieremiam XXII de viro iusto: Erat, ${ }^{207}$ inquit, quasi lignum transplantatum de ecclesia malignancium in ecclesiam confitencium super aquas, et sequitur: Erit ${ }^{208}$ folium eius viride ${ }^{209}$ et in tempore siccitatis non etc. Non sic de peccatoribus, quia ipsi sunt arbores ${ }^{210}$ infructuose, II Petri III, autumpnales, eradicate, bis mortue, in ${ }^{211}$ anima scilicet et corpore. Arbores ${ }^{212}$ autumpnales infructuose sunt secundum Glossam, aut acerbum fructum faciunt, sic peccatores: si fructum faciunt, malum faciunt et non bonum, Sapiencie III: Fructus ${ }^{213}$ eorum inutiles et acerbi ad manducandum. Sed viri iusti bonum faciunt fructum, quia bonorum ${ }^{214}$ laborum gloriosus est fructus.

8. Est igitur fructu fecundus in proficientibus, est eciam situ delectabilis et amenus in perfectis, quorum conversacio ${ }^{215}$ est in celis, Philippensium III, per amorem scilicet et desiderium supernorum. Conversacio peccatorum in terra est, non in celo, ipsi enim sunt, qui ${ }^{216}$ habitant domos lu|teas $\left(177 \mathrm{r}^{\mathrm{b}}\right)$ et terrenum ${ }^{217}$ habent fundamentum, Iob 4 . Hoc eciam, quod dicitur Matthei III: Vulpes ${ }^{218}$ habent foveas. Vulpes sunt dolosi peccatores, quorum consciencia spelunca latronum, quia dolos ${ }^{219}$ tota die meditabantur. Foveas habent

203 Sir 24, 42.

204 Gn 26, 19.

205 Io 4, 10.

206 corr. $e$ fructifero $L$.

207 erat ... aquas: cf. Ier 17, 8 .

208 Ier 17, 8.

209 corr. $e$ virtor $L$.

210 Iud 12.

211 Glossa ordinaria interlin. ad Iud 12 ad „bis mortue“(Rusch [ed.] IV, fol. 193v $\left.v^{\mathrm{b}}\right)$.

212 arbores ... bonum: cf. Glossa ordinaria marg. ad Iud 12 ad „arbores autumnales“, Glossa ordinaria int. ad „infructuose" (Rusch [ed.] IV, fol. 193v" ).

213 Sap 4, 5.

214 Sap 3, 15.

215 Phil 3, 20

$216 \operatorname{Iob} 4,19$.

217 terrenum ... fundamentum: emendavi terrenas haberi faciat $L$.

218 Mt 8, 20.

219 Ps 37, 13. 
in terra ita, ut dicunt: Adhesit ${ }^{220}$ in terra venter noster, sed volucres ${ }^{221}$ celi, id est spirituales et perfecti, habent nidos, volant enim amore et desiderio supernorum ita, ut quasi admirans dicit propheta Ysaias: Qui ${ }^{222}$ sunt isti, qui ut nubes volant, et Iob 39: Numquid ${ }^{223}$ ad preceptum tuum elevabitur aquila et in arduis ponet nidum suum? Quasi diceret: Ad tuum et non ad meum preceptum. Aquila, qui videt solem in rota, est vir contemplativus, qui mentis oculo videt solem iusticie in rota eternitatis sue. Ille ad preceptum Domini elevatur pennis devocionis et in arduis ponit nidum sue quietis. Ecce ergo, quomodo militans ecclesia est situ delectabilis et amena in viris perfectis, propter quod merito dicitur paradysus voluptatis!

9. In isto paradyso posuit Deus hominem, prelatum scilicet, qui a Deo debet institui, non ultro se ingerere, non impudenter inferre, non violenter intrudere: $\mathrm{Nemo}^{224}$ enim sibi assumat honorem etc., Hebreorum 4. Sed attende, quam provide dicit: Nemo sibi assumat honorem. Non dicit: Assumet, quia pro tempore suo loquebatur. Apostoli enim tunc in eleccione sua et divinum querebant consilium et exspectabant responsum, sicut electus fuit beatus Mathias et Nycolaus. Non ergo dixit: Assumet, quod pro tempore isto verbum apostoli calumpniam haberet, quia multi nunc ingerunt se inpudenter, ultro se offerunt, iam enim regnum ${ }^{225}$ celorum vim patitur et violenti diripiunt illud. Itur ad curiam et reditur et Romane familiaritates magis sumptibus acquiruntur. Sciunt enim verum esse, quod dicit Matthei VIII: Audiunt ${ }^{226}$ igitur Iudei, quod Romani potentes sunt viribus, et post multa sequitur: Quibus ${ }^{227}$ vellent $^{228}$ esse auxilio Romani, ut regnarent, regnabant, quos vero vellent, regno detrudebant. Ideo ibi primo vacantes petuntur, executores favorabiles impetrantur et mire ambicionis et cupiditatis insania vivencium desiderant mortes, ut fiant ${ }^{229}$ successores.

10. Audi gressum miserabilem ascenden $\mid \mathrm{di}\left(177 \mathrm{v}^{\mathrm{a}}\right)$ ad dignitatem: Est aliquis <abbas> vel presbyter morte vicinus, quia infirmus senex. Statim accidit monachis illius abbacie vel canonicis illius ecclesie, quod legimus discipulis adhuc infirmis accidisse Matthei, quod cum predixissset Dominus mortem suis discipulis dicens: Ecce $e^{230}$ ascendimus Iherosolymam etc., facta ${ }^{231}$ est contencio inter eos, quis eorum videretur esse maior. Sic appropinquante morte prelati fit contencio etc., fiunt consilia, ${ }^{232}$ texuntur recia ad capiendum

220 adhesit ... meus: cf. Ps 43, 25.

221 Lc 9, 58.

222 Is 60, 8.

223 Iob 39, 27.

224 nemo ... honorem: cf. Hbr 5, 4.

225 Mt 11, 12.

226 audiunt ... viribus: $c f .1$ Mcc 8,1 .

$2271 \mathrm{Mcc} 8,13$.

228 emendavi sec. 1 Mcc 8, 13. vellet $L$.

229 fiat $L$.

230 Mt 20, 18.

231 Lc 22, 24.

232 emendavi consilio $L$. 
cornutam bestiam, episcopalem scilicet dignitatem. Cum autem mortuus fuerit, tunc collidentur ${ }^{233}$ parvuli in utero Rebecce, scilicet matris ecclesie, sicut dicitur Genesis. Unus enim contendit adversus alium, quia quilibet vult eligere suum, quod optime signatur Genesis, ubi dicitur, quod Thamar ${ }^{234}$ vidua concepit de Iuda duos filios et appropinquante partu alter protulit ${ }^{235}$ manum et dixit obstetrix: Iste eggreditur prior, illo ${ }^{236}$ autem retrahente manum suam alter eggressus est. Thamar vidua mater est ecclesia pastore viduata, que de Iuda duos filios concepit, quia de aliquo proditore vel sedicioso, qui turbat pacem eligencium et non sinit $\operatorname{eos}^{237}$ convenire ad aliquem unum et ita facit, ut duo eligantur. Obstetrix, qua iuvante et procurante post egreditur, est aliquis procurator, per quem in curia negocium procuratur. Cum autem unus ${ }^{238}$ profert manum largicionum ad munera, tunc dicit: Iste eggreditur prior, id est iste, qui largus est, prius obtinebit, sed illo retrahente manum, id est cessante a muneribus, alter egreditur ad prelacionem, quia solus qui ${ }^{239}$ perseveraverit in finem, ille salvus erit. Ecce pugna pro prelacione obtinenda, que obtime signatur II Regum, ubi dicit ${ }^{240}$ illa mulier ${ }^{241}$ thecuides: Heu mulier vidua sum ego. Ita plangit ecclesia desolacionis huius malum, cuius vir mortuus est prelatus defunctus, duo filii sunt electi rixantes in $^{242}$ agro, scilicet Romane curie. Que rixa ager dicitur, de agro enim fructus non colligitur, nisi prius excolatur, sic Romana curia nisi inseratur, solum spinas $^{243}$ et tribulos germinabit tibi. In ${ }^{244}$ isto ergo agro rixati sunt duo et nullus erat, qui prohibere posset, id est valet, $\left(\mid 177 \mathrm{v}^{\mathrm{b}}\right)$ et percussit alter alterum aliquando per notam infamie opponendo vel falsum crimen inponendo, et sic interficit eum quantum ad infamiam. Ecce quomodo violenter hic mores capiuntur et hoc intellige idem de minoribus.

11. Contingit forte aliquem in abbatem eligi, qui si forte pati repulsam timeat, quod sibi conscius, quod nec vita nec sciencia suffragatur ei, tunc mittit angelum, ${ }^{245}$ id est nuncium suum, qui percuciat latus Petri et dicat: Surge velociter! Latus Petri, collaterales episcopi, percuciuntur quandoque non malleo ferreo, sed argenteo, et dicit: Surge velociter, antequam veniant adversarii, et persuade episcopo de tali electo! Tunc illi, $i n^{246}$ quorum manibus iniquitates sunt et dextera eorum repleta muneribus, licet sinistra semper sit vacua et ad recipiendum parata, vadunt ad iustificandum impium pro muneribus et

233 collidentur ... Rebecce: cf. Gn 25, 22.

234 Thamar ... egressus est: cf. Gn 38, 18-29.

235 emendavi sec. Gn 38, 27. pertulit $L$.

236 emendavi sec. Gn 38, 29. ille $L$.

237 emendavi eas $L$.

238 una $L$.

239 Mt 10, 22; 24, 13.

240 emendavi dicitur $L$.

2412 Sm 14, 4-6.

242 emendavi enim $L$.

243 Gn 3, 18.

$2442 \mathrm{Sm} \mathrm{14,} 6$.

245 angelum ... velociter: $c f$. Act 12, 7.

246 Ps 25, 10. 
dicunt: Laudabiliter fecerunt monachi eligendo talem, non ${ }^{247}$ est alter talis. Alter dicit: $N_{o n}{ }^{248}$ est inventus similis illi. Alius dicit: Dignus es, domine, ut hoc illi prestes. Sic donum $^{249}$ hominis dilatat viam eius et ante principes spacium ei facit. In cuius figura dicitur ${ }^{250}$ Dominum precepisse, ut super archam federis poneretur ${ }^{251}$ propiciatorium de auro purissimo, Exodi XXI. Si enim aurum purissimum super archam positum fuerit, mirabiliter facit propicios tales advocatos, qui ${ }^{252}$ post aurum abeunt et sperant in peccunie thesauris, sed optenta confirmacione et recepta benediccione pro graciarum accione. Ille episcopus pabestridum $^{253}$ vinum vel aliquid tale obtulit, meminisse ${ }^{254}$ debet illius verbi: Exiguum ${ }^{255}$ munus etc. Sic eciam in minoribus prelacionibus faciunt. Statim cum aliquid vacat, pro nepotibus et amicis cogant facientes illud Ysaie: Apprehendet ${ }^{256}$ unusquisque fratrem suum domesticum, dicens: Vestimentum tibi est, esto princeps noster; princeps enim esto, qui enim curam non habet suorum et est interior. Per tales gradus plerique ad altare ascendunt, quod est contra legem. Omnes ${ }^{257}$ enim principes dixerunt: Hereditate possideamus. Hebreorum propter hec signanter dixit apostolus: Nemo sibi assumit $\left(\mid 178 \mathrm{r}^{\mathrm{a}}\right)$ honorem.

12. Posuit, inquit, hominem in paradysum voluptatis. Per hoc, quod dicit: hominem, insinuat, qualis enim apcius ${ }^{258}$ debet esse, homo enim prelatus debet esse. Et quid est homo? Animal ${ }^{259}$ racionale mortale. Si homo es, animal debes esse et animal ${ }^{260}$ est substancia animata sensibilis. Ad hoc ${ }^{261}$ ergo, ut animal sis, debes esse substancia, non accidens. Hec dico propter quosdam prelatos, qui in se naturam accidentis reputant. Accidens ${ }^{262}$ est enim, quod adest et abest, unde ille, qui non est in persona propria, sed in alia ecclesia deservit, accidens est, quia aliquando assunt, aliquando absunt. Vadunt ad tondendas oves, non ad pascendum, quod optime insinuatur Proverbiorum VII in verbis illius mulieris, que dicebat: Non ${ }^{263}$ est vir in domo sua, abiit via longissima, ${ }^{264}$ sacculum pecunie secum tulit, in die plene lune reversurus. Ita potest dicere ecclesia in hyeme: Non est vir mecum in

$2471 \operatorname{Rg} 21,25$.

$248 \operatorname{Sir} 44,20$.

249 Prv 18, 16.

250 emendavi domino $L$.

251 poneretur ... purissimo: cf. $\operatorname{Ex} 25,17$.

$252 \operatorname{Sir} 31,8$.

253 sic!, corr. $e$ pabestrido $L$.

254 corr. $e$ monuisse $L$.

255 Disticha Catonis 1, 20 (Baehrens [ed.] 1881: 210).

256 Is 3, 6.

257 omnes ... principes: corr. sec. Ps 81, 12-13. omnis enim princeps $L$.

258 emendavi apccius $L$.

259 Porphyrius, Isagoge sec. trans. Boethii (Minio-Paluello [ed.] 1966: 18, 14).

260 Porphyrius, Isagoge sec. trans. Boethii (Minio-Paluello [ed.] 1966: 16, 22-23).

261 emendavi hanc $L$.

262 Porphyrius, Isagoge sec. trans. Boethii (Minio-Paluello [ed.] 1966: 20, 7).

263 Prv 7, 19-20.

264 emendavi longissimi $L$. 
parietibus ${ }^{265}$ ecclesie, abiit illuc vel illuc, sacculum pecunie tulit secum in die plene lune, id est autumpno, reversurus, quando plena erit horrea blado et horrea vino, ut scilicet vendat et recedat, quia de ove non curat, dummodo vellus habeat. Similes illi propinquo Ruth, ${ }^{266}$ qui ager volebat habere, sed Ruth nolebat ducere.

13. Unde tales sunt de genere accidencium, in quantum adsunt et absunt, sed differunt in hoc ab accidente, quia hoc non fit sine subiecti ${ }^{267}$ et ecclesie corrupcione. ${ }^{268}$ Unde Dominus induxit diluvium super genus humanum, cuius racio est, quia omnis ${ }^{269}$ caro corruperat viam suam. Videntes ${ }^{270}$ enim filii Dei, id est ecclesiastici, quod uxores aliorum sint pulcre, accipiunt sibi ex omnibus. Unde bene possunt dicere ad episcopos suos cum Laban: Oves ${ }^{271}$ tue steriles non fuerunt, quia certe gravide facte sunt. Dicunt tamen tales quandoque cum Abraham Sare, uxori sue, Genesis XX: Dic,, ${ }^{272}$ obsecro, quod soror mea sis ${ }^{273}$ etc. Unde contigit, quod Doec ${ }^{274}$ Ydumeus interfecit sacerdotes Domini. Doec Ydomeus est motus carnis et spiritus, qui aliquando interficit racionem. Hoc ergo ${ }^{275}$ pro $^{276}$ parte verum est, quod dicitur Machabeorum VII: Templum ${ }^{277}$ commessacionibus et luxuria plenum erat et cytharizancium cum meretricibus et supra IIII $^{\circ}$ in eodem. Tales itaque a natura accidencium degenerantur, quod substancias corrumpunt, ideo non inmeri| to (178 $\left.\mathrm{r}^{\mathrm{b}}\right)$ timere possunt, quod dixit Dominus de talibus corruptoribus: Corrupta ${ }^{278}$ est terra, id est porrochia, a facie eorum et ego dispergam eos de terra. Non sic facientes, karissimi, sed in hoc naturam accidencium servare debetis, ut non corrumpatis, sed naturam substancie, quia semper ecclesie debet presens esse!

14. Debet esse substancia animata, quia prelati non solum debent esse animati ab anima, sed ab animo, scilicet ad domandum rebelles. Sicut dicit Dominus ad Iob XL: Disperge $e^{279}$ superbos in furore tuo et respiciens ${ }^{280}$ omnem arrogantem humilia. Sed plerumque vertitur ${ }^{281}$ folium, quia superbus divitibus parcitur, pauper conteritur, contra folium, quod a vento rapitur, ostendunt aliqui potenciam suam. Et tunc tales similes Sauli, de quo I Regum XV,

265 emendavi paribus $L$.

266 Cf. Rt 3, 4-6.

267 subiecti ... corruptione: cf. Porphyrius, Isagoge sec. trans. Boethii (Minio-Paluello [ed.] 1966: 20, 7-8).

268 corr. $e$ percorrupcione $L$.

269 Gn 6, 12.

270 Gn 6, 2.

271 Gn 31, 38.

272 Gn $12,13$.

273 corr. $e$ sit $L$.

274 Doec ... Domini: cf. 1 Sm 22, 18.

275 emendavi erga $L$.

276 emendavi per $L$.

2772 Mcc 6, 4.

278 Gn 6, 11.13.

279 Iob 40, 6.

280 emendavi respicientem $L$.

281 sequitur quia deletum $L$. 
quod cum precepisset Dominus, ut Amalech disperderet, pepercit ${ }^{282}$ regi Agos Amalech et universis ovibus et gregibus, quod pulchrum erat, vile autem disperdidit. Sic plurimum fit in ecclesia: pauperes arguuntur, pingwiores reservantur, Ihesus occiditur et Barrabas dimittitur. Unde Salomon in Ecclesiastes V hoc esse, quod commune ubique, et ideo dicit non esse mirandum: $S i^{283}$ videris, inquit, collumpnas ${ }^{284}$ egenorum subverti et violenta iudicia et iusticiam in provinciis subverti, non mireris super hoc negocio. Quasi diceret: Hoc est commune et quasi naturale. Video aliquid simile in natura: Aves rapaces sibi mutuo parcunt, alias rapiunt, ut milvus pullum, non milvum, similiter piscis magnus comedit minorem. Sic faciunt homines, unde Abacuc II: Facies ${ }^{285}$ hominis sicut pisces ambulantes super terram, ut scilicet maior comedat minorem. Et mirabile est de quibusdam hominibus: non possunt videre deprope, sed delonge, in extrema parte dyocesis vident maculas in sacerdote et in hospicio suo non vident, vident ${ }^{286}$ festucam in alio et in se non vident trabem. Tales sunt similes vulturibus, qui ad cadavera venerunt quingentis leucis.

15. Unde prelatus debet esse substancia animata, id est animosa ad corrigenda crimina, sed ulterius debent esse sensibiles per compassionem penitentis, quia animositas sine compassione degenerat in crudelitatem. Unde debent esse tales sensibiles, ut videlicet quod $\left(\mid 178 v^{a}\right)$ conpassionem senciunt, spirituales quam corporales miserias subditorum. Unde bonus prelatus dixit: Quis ${ }^{287}$ infirmatur et ego etc. Talis fuit sanctus Nycolaus, qui super afflictos pia gessit viscera. Unde apostolus: Non ${ }^{288}$ habemus pontificem, qui non possit conpati nobis. In huius rei figuram legimus II Regum VI, quod in templo fecit Salomon $d u o^{289}$ hostia de virgis olivarum. Hostia sunt prelati, qui debent esse de virgis olivarum, id est conpacientes. Et hoc est, quod dicitur III Regum VII, quod bases ${ }^{290}$ templi fusiles $^{2}$ erant. Bases sunt prelati, qui debent esse fusiles, ut ad modum metalli diffundantur per compassionem. Maxime autem neccessaria compassio in correpcione, ne assit zelus districcionis sine conpassione pietatis. Unde possit dicere: Factum ${ }^{291}$ est cor meum tamquam cera liquescens etc. Unde apostolus: $\mathrm{Si}^{292}$ preoccupatus fuerit homo in delictis etc. Considerans te ipsum, quam fragilis sis ad resistendum, quam pronus ad cadendum, quam impotens ad surgendum, ut ex consideracione tui movearis ad compassionem proximi et sis substancia substanciata, animata, sensibilis, oportet te eciam esse racionabilem.

282 pepercit ... gregibus: cf. 1 Sm 15, 15 .

283 Ecl 5, 7.

284 calumnias Vulgata.

$285 \mathrm{Hab} 1,14$.

286 vident ... trabem: cf. $M t 7,3$.

2872 Cor 11, 29.

$288 \mathrm{Hbr}$ 4, 15.

$2891 \operatorname{Rg} 6,32$.

290 bases ... fusiles: $c f .1 \operatorname{Rg} 7,30$.

291 Ps 21, 15.

292 Gal 6, 1. 
16. Racionales oportet esse prelatos ecclesie, non ydiotas, non bruta. Unde Dominus per Malachiam: Labia, ${ }^{293}$ inquit, sacerdotis custodiunt scienciam, et Ieremie XX hoc per figuram habemus. Genesis $\mathrm{XL}^{\mathrm{a}}$ dicebat pharao ad Iosep: $\mathrm{Si}^{294}$ nosti in fratribus tuis viros industrios, illos constitue magistros, ${ }^{295} \mathrm{ut}^{296}$ sciant scilicet distinguere inter lepram et lepram. In cuius figura legitur in collumpnis templi conscripta cherubin, quod interpretatur plenitudo sciencie. Hinc est, quod precepit Dominus Moysi ponere ${ }^{297}$ in racionali doctrinam et veritatem. Polleat igitur prelatus veritate, operacione et doctrina verborum, ut sit industrius, non fatuus, alioquin a Domino reprobatur dicente: Quia ${ }^{298}$ repulisti scienciam, repellam te, ne sacerdocio fungaris mihi, Osee IIII.

17. Ulterius debet esse mortalis, ut sicut est mortalis in veritate, sic sit in consideracione, ut semper novissima providentes numquam peccent. Bernhardus: Sapiens, ${ }^{299}$ inquit, in omnibus semper sua novissima conmemorans, ante mortem cause sue dictat iudicium et quasi presente cadavere fodit sepulcrum. Plangencium multitudo et subsequitur et precedit, et de pre $\mid$ sentibus $\left(178 \mathrm{v}^{\mathrm{b}}\right)$ et preteritis multum est, quo se unusquisque examinans lugeat, ubi tota vita contra conscienciam clamat. Sic igitur cogitacio mortis reprimit vim elacionis.

18. Sit igitur sic prelatus homo, quia Deus posuit in paradyso hominem, non leonem. Dicitur in naturalibus, ${ }^{300}$ quod in leone est fetor anhelitus, per quod signatur fetor et vicium sermonis in prelatis, quod maxime ipsis cavendum. Ipsis enim dicitur: Omnis ${ }^{301}$ sermo malus ab ore vestro non procedat. Ipsi enim exemplum debent esse in opere et sermone. Debent eciam $i n^{302}$ pondere ${ }^{303}$ et mensura omnia facere, in pondere, quod excludit multiloquium, in mensura, quod excludit falsiloquium. Sed mensura sermonis debet esse regula veritatis. Mensura prelatorum debet esse sicut mensa religiosorum, in qua unus legit et alter corrigit. Si enim semper legeret et non corrigeret, fieret barbarismus ${ }^{304}$ et soloecismus, id est detracciones, multiloquia. Unde contingit aliquando, quod Herodes $^{305}$ amputat in mensa caput Iohannis Baptiste. Sed multi sunt, qui carnes ${ }^{306}$ crudas et coctas simul comedunt, quorum ${ }^{307}$ os malediciccione et amaritudine plenum est, scilicet

293 Mal 2, 7.

294 Gn 47, 6.

295 emendavi magistras $L$.

296 ut ... lepram: cf. Dt 17, 8 .

297 ponere ... veritatem: $c f$. Ex 28,30 .

298 Os 4, 6.

299 Ernaldus Bonaevallis, De operibus sex dierum (Migne [ed.] 1854: PL 189, col. 1554C-D).

300 non inveni.

301 Eph 4, 29.

$302 L v 19,35$.

303 emendavi baribatus $L$.

304 emendavi barbatus contractum L.

305 Herodes ... Baptiste: cf. Mt 14, 10-11.

306 carnes ... comedunt: cf. Ex 12, 9.

$307 \mathrm{Rm} \mathrm{3,} 14$. 
detraccione. Sepulcrum ${ }^{308}$ patens est fetens guttur eorum, unde signatur per illam bestiam Apokalypsis 13, de qua dicitur, quod habebat ${ }^{309}$ os leonis, quod fetidum. Non debet esse tale os prelatorum. Item non debent rapaces ungwibus, scilicet per avariciam, nec voraces dentibus, scilicet per gulam. Utrum vigeat peccatum in prelatis, respondet Ieremias: $A^{310}$ magno usque ad minorem omnes avaricie student. De gula dicitur Amos: Ve, ${ }^{311} q u i$ opulenti estis in Syon etc.

19. Non debent igitur esse prelati bestiales, sed homines, quia Deus posuit hominem in paradyso voluptatis non, ut ocio torpet, sed ut operaretur et custodiret illum. Unde apostolus ad Thymoteum: Vigila in omnibus, labora, opus fac ewangeliste. Debent eciam prelati custodire, ut Regum: Custodi ${ }^{312}$ virum istum. Ve illis, qui dicturi sunt: Vineam ${ }^{313}$ meam non custodivi, sed exterminavit ${ }^{314}$ eam aper de silva.

Rogemus Dominum, ut vineam ${ }^{315}$ in paradyso ecclesie consociati custodiamus, ut ad eterna gaudia perveniamus. Quod nobis prestet, qui vivit et regnat per omnia secula seculorum, amen.

308 Ps 5, 11.

309 habebat ... leonis: cf. Apc 13, 2.

310 Ier 6, 13.

311 Amos 6, 1.

$3121 \operatorname{Rg} 20,39$.

313 Ct 1, 5.

314 Ps 79, 14.

315 Sequitur meam deletum $L$. 
